Portland State University

PDXScholar

1973

\title{
A Study Describing Pastoral Counseling Among the Christian Church ministers in Oregon, with special emphasis on the counseling Training That They Received at Northwest Christian College
}

Thomas O. Woodruff

Portland State University

Follow this and additional works at: https://pdxscholar.library.pdx.edu/open_access_etds

Part of the Social Work Commons

Let us know how access to this document benefits you.

\section{Recommended Citation}

Woodruff, Thomas O., "A Study Describing Pastoral Counseling Among the Christian Church ministers in Oregon, with special emphasis on the counseling Training That They Received at Northwest Christian College" (1973). Dissertations and Theses. Paper 1711.

https://doi.org/10.15760/etd.1710

This Thesis is brought to you for free and open access. It has been accepted for inclusion in Dissertations and Theses by an authorized administrator of PDXScholar. Please contact us if we can make this document more accessible: pdxscholar@pdx.edu. 
A STUDY DESCRIBING PASTORAL COUNSELING AMONG THE CHRISTIAN CHURCH MINIST ERS IN OREGON, WITH SPECIAL EMPHASIS ON THE COUNSELING TRAINING THAT THEY RECEIVED AT NORTHWEST CHRISTIAN COLLEGE

by

THOMAS O. WOODRUFF

A report submitted in partial fulfillment of the requirements for the degree of.

MASTER OF

SOCIAL WORK 
TO THE OFFICE OF GRADUATE STUDIES:

The members of the Committee approve the practicum of Thomas O. Woodruff, presented May 17, 1973.

L. Jay Conrad, Chairman

APPROVED:

Dr. Gordon Hearn, Dean of the School of Social Work

May 17,1973

Df. Lawrence Bixler

( 
LIST OF TABLES ...................... iii

LIST OF ILLUSTRATIONS . . . . . . . . . . . . iv CHAPTER

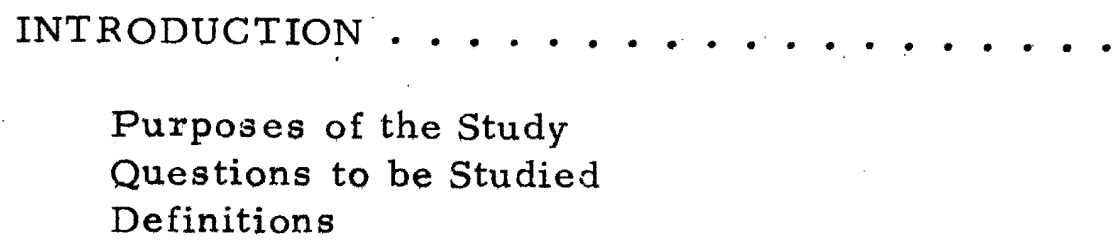

Purposes of the Study Questions to be Studied Definitions

REVIEW OF THE LITERATURE. . . . . . .

Selection of Sample

Collection of Data

Data Processing

IV

PRESENTATION AND INT ERPRETATION OE

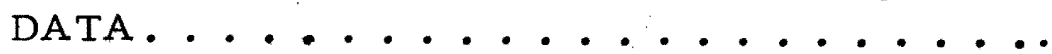

$\mathrm{V}$

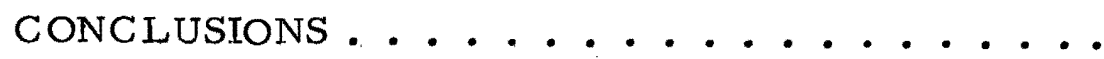

Results

Impact for Northwest Christian College

Implication for Further Research

FOOTNOTES. . . . . . . . . . . . . . . .

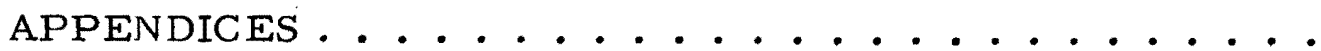

A. Questionnaire

B. Letter to the Ministers

C. Frequency and Percentage Distribution of the Importance of Pastoral Duties to the Minister, His Board, and the Congregation 
FREQUENCY AND PER CENTAGE DIST RIBUTION OF:

\begin{tabular}{|c|c|}
\hline I & Years In Current Ministry \\
\hline II & Size of Church \\
\hline III & Size of Town \\
\hline IV & $\begin{array}{l}\text { How Pastoral Counseling is Different from other } \\
\text { Kinds of Counseling }\end{array}$ \\
\hline $\mathrm{V}$ & $\begin{array}{l}\text { Importance of Couns eling to Minister, the Board, } \\
\text { and the Congregation }\end{array}$ \\
\hline VI & Amount of Time Spent per Week in Counseling \\
\hline VII & Primary Reasons Pastoral Counseling is Sought \\
\hline VIII & $\begin{array}{l}\text { How Often Identified Procedures are Used in an } \\
\text { Average Counseling Session }\end{array}$ \\
\hline IX & $\begin{array}{l}\text { The Year Graduated from Northwest Christian } \\
\text { College }\end{array}$ \\
\hline $\mathrm{X}$ & Seminary Attended \\
\hline $\mathrm{XI}$ & Institutes and Seminars Attended \\
\hline XII & $\begin{array}{l}\text { How Helpful Training has been in Preparing the } \\
\text { Minister for the Role of Couns elor }\end{array}$ \\
\hline XIII & $\begin{array}{l}\text { Level of Agreement Regarding Suggestions for the } \\
\text { NCC Counseling Program }\end{array}$ \\
\hline XIV & Who Initiates the Counseling Process \\
\hline $\mathrm{XV}$ & $\begin{array}{l}\text { Average Number of Counseling Sessions with } \\
\text { Any one Individual or Family }\end{array}$ \\
\hline XVI & $\begin{array}{l}\text { How Often People are Referred by the Minister } \\
\text { to Specified Resources }\end{array}$ \\
\hline
\end{tabular}


LIST OF ILLUSTRATIONS

FIGURE

PAGE

I Top Priorities of the Minister and His Perception of the Priorities of the Board and Congregation

II Problem Areas as Often or Almost Always the Reason Counseling was Sought

III Most Frequently Used Procedures of the Minister During an Average Counseling Session

IV Ministers Who Agree and Disagree with Various Suggestions Regarding the NCC Counseling Program

$\mathrm{V}$ Sources that Often or Almost Always Initiated the Counseling Process

VI Occasional and Often used Resources for Referral Purposes 
CHAPTER I

IN'TRODUCTION

PURPOSES OF STUDY

Pastoral Counseling is recognized by many people with the Church as one of the expected duties of the Minister. It is built into his role as Spiritual and moral leader of the people within the Congregation. Although this concept of the Minister varies among denominations and churches, it appears to be fairly consistent within the Christian Church.

It was out of an interest and concern for both the Christian and mental health, that a study about Pastoral Counseling was conceived. It was hoped that such a study would clarify what was involved in Pastoral Counseling and how it was related to other kinds of Counseling. There was relatively little information on the general subject of Pastoral Counseling, and nothing could be found which dealt specifically with Pastoral Counseling among Ministers of the Christian Church. Although most of the literature was written within a basic Protestant framework, much of the work was aimed at instructing Ministers on how to be Counselors rather than to describe the nature and extent of Pastoral Counseling. In order to obtain that descriptive information it was determined that a survey would be made of a sample of Christian Church Ministers in Oregon. By holding the variables "denomination" and location con-. stant, it was felt that more inferences could be made from the sample to the total population. 
A preliminary questionnaire was prepared and discussed with various Ministers and research people at the Portland State University School of Social Work. Although that questionnaire was found to be inadequate for the needs of the study, the concept of the study was approved and welcomed by both ministers and researchers.

Beyond contributing descriptive information about Pastoral Counseling among the Christian Church Ministers in Oregon, the study was designed to allow the Ministers to evaluate the training that they had received in Counseling. Since Northwest Christian College in Eugene, Oregon graduated over 70 percent of the Christian Ministers in Oregon and the Northwest, it seemed appropriate that their. Counseling Program should be evaluated specifically. While little was known about the quality of the Counseling Curriculum at Northwest Christian College (NCC), knowledge of its limited quantity raised questions as to how effective it could be in preparing Ministers to do Professional Counseling. The informal hypothesis of the study was that these Christian Church Ministers who graduated from NCC were doing extensive Counseling without sufficient training or preparation. Although the Ministers' Counseling effectiveness could not be determined just by surveying the Ministers, they could evaluate how effective their education had been in preparing them to do Counseling.

The concept of having Ministers evaluate the Counseling Program at NCC required the survey to be directed only to Ministers who 
graduated from NCC. Dr. Lawrence Bixler, who heads the Psychology and Counseling Department at NCC supported the study, and could recall no similar research which had ever been directed to NCC graduates. He felt that the results would be helpful in building a Counseling Program which would be more sensitive to the needs of the Minister after he graduated and went into a full-time Ministry.

It was also felt that the study might be helpful to other Practitioners in the helping professions, if they understood more fully how a Minister was trained in counseling and why, who, and how he counseled.

The research was not designed to make value judgments as to the effectiveness of Pastoral Counseling. However, it has provided a general overview of Pastoral Counseling based on the literature, and much descriptive information about Pastoral Counseling within a specific population. Also, it has reported the Ministers' own evaluation of the Counseling Training that they have received, as well as their opinions regarding the NCC Counseling Program.

No inferences can be made to Ministers outside of the study population, but some implications and recommendations have been made from within that population.

\section{QUESTIONS TO BE STUDIED}

Essentially there were five basic questions which the research was designed to answer. They were as follows: 
1. How important is Counseling to the Ministers and how much time is devoted to it per week?

2. What kinds of problems does the Minister usually deal with in his Counseling Sessions?

3. What Techniques, Procedures, or Skills does the Minister utilize within the Counseling process?

4. How are people referred to the Minister for Counseling, and how often and where does he refer them elsewhere?

5. How do the Ministers evaluate the Training that they have received in Counseling and what suggestions, if any, do they have regarding the Counseling Program at Northwest Christian College?

\section{DEFINITIONS}

The following operational definitions were used in this research:

1. Counseling and Pastoral Counseling--Part of the purpose of this study was to define these terms, therefore, they will be dealt with extensively in the next chapter.

2. Christian Church--used in a specific sense to refer to an undenominational fellowship of Christians who utilize the New Testament as their Standard for Faith and practice. Used interchangeably with the Church of Christ. There are 170 independent Christian Church Congregations in Oregon.

3. Minister-Pastor--These two terms have been used interchangeably and refer to an ordained, legally recognized person 
responsible to a local congregation. The research was directed only to full-time, paid, Senior Ministers of the Christian Church or Church of Christ in Oregon, who received their undergraduate education from Northwest Christian College.

4. Evangelical--A body of Protestants who especially emphasize the Authority of the New Testament and are fundamental in their Biblical interpretations. 


\section{CHAPTER II}

\section{REVIEW OF THE LITERATURE}

This review will attempt to give a general overview of Pastoral Counseling. It has been divided into four sections, each dealing with a specific aspect of Pastoral Counseling. The sections are as follows:

1. Introduction

2. Definitions

3. Historical Development

4. Similarities and differences between Pastoral Counseling and other kinds of Counseling

\section{Introduction}

The assumption that Ministers are often called upon to give Counseling is supported by a study that the University of Michigan published in 1960 (Gurin 1960) ${ }^{1}$. They made a Nationwide survey to determine where people with emotional problems were most apt to go for help. It was found that one in every seven interviewed had sought professional help for some kind of conflict or emotional problem. Of those who had sought professional help, 42 percent first went to a Clergyman, 29 percent to non-psychiatric physicians, and the remaining 31 percent had sought out traditional mental health professionals. If the respondant was a Protestant and attended church at least once a week, the chances were better than 50 percent that he would first seek out the Minister. 
These figures indicate that, for whatever reason, a large segment of the population seek out the Minister when they need guidance, comfort, or couns eling.

\section{$\underline{\text { Definitions }}$}

The literature and the study itself revealed that there was a wide range of thinking as to what Pastoral Counseling was. It was impossible to even find one comprehensive definition for just the word "Counseling" which was accepted by all Counselors. The dictionary $(1969)^{2}$ defines counseling simply as "to give guidance or advice". Edwin Lewis in his book The Psychology of Counseling, $(1970)^{3}$, provides a more complete, yet cumbersome definition of Counseling as: "A process by which a troubled person is helped to feel and behave in a more personally satisfying manner through interaction with an uninvolved person, who provides information and reactions which stimulate the client to develop behaviors which enable him to deal more effectively with himself and his environment".

While this is probably not the best definition, it does reflect some of the processes involved in Counseling. Many ministers, however, would not find Lewis's definition adequate. They define counseling from a Spiritual or Biblical basis. Because of that orientation, much of the literature on Pastoral Counseling is difficult to understand unless the reader is familiar with Biblical terms and concepts. 
Hiltner $(1961)^{4}$ states "The minister has several functions but only one task. His functions include preaching, counseling, teaching, evangelizing, conducting worship, and leading the social outreach of the church into the world. His central task, however, is to bring men into conscious acknowledgement of their dependence upon Jesus Christ as Lord and Savior, and aiding them in that $F$ aith, to live still imperfect but Christian lives".

This emphasis on knowing Christ, and living a Christian life, is more than helping a person feel and behave in a more personally satis fying manner as Lewis attempts. Although Hiltner defines the goal of Pastoral Counseling differently, he still ascribes to it the same basic process and techniques as is found in other kinds of counseling. Donald Tweedie $(1963)^{5}$ does not agree. He states:

"In Pastoral Counseling the chief reliance is not on the principles of Psychology or psychiatry, but on the spiritual power released through $\mathrm{F}$ aith in God. His Ministry to individuals will therefore go beyond that of professional therapists who limit themselves to the Sciences of the mind. The Pastor's task is to set the whole life of the troubled individual in a Christian context, and help him discover the healing power of Divine love in human and human-Divine relationships". This concept of the "Healing Power of Divine Love" is also voiced by Clinebell $(1966)^{6}$ who believes that the Pastor's goal in Counseling is 
to release whatever is blocking this God-given resource within the person. Pastoral Counseling is therefore seen in terms of reconciliation-that of removing whatever has separated and alienated man from God. His feelings about himself, and relationships with others are thought to be dependent upon his relationship with God. Laycock $(1961)^{7}$ believes this emphasis on a relationship with Godis only a specialized part of Pastoral Counseling. It is in this area that the Pastor deals with the Spiritual side of man, or his religious problems. In a wider sense, Pastoral Counseling is aimed at the problems and conflicts in everyday life, which are sometimes separate from Spiritual matters. Tweedie $(1963)^{8}$ does not see a distinction, but states that the goal is similar to the challenge as put forth by the Apostle Paul in the Book of Romans "to not be conformed to this world, but to be transformed by the renewing of your mind". To Tweedie then, the task of Pastoral Counseling is not to make men fit in better with their environment, but to help them become a new person.

The various thoughts regarding what Pastoral Counseling is, suggests that there is no single definition which is accepted by all authors and Ministers. Consequently, it is probable to assume that the Minister's own individual philosophy about God and man, as well as what the Church believes, determines largely how Pastoral Counseling is defined and practiced.

Another method of understanding more fully what Pastoral 
Counseling is, is to look at it historically and see how it has developed through the years.

\section{Historical Development}

Although it has only been within the last 50 years that Pastoral Counseling has really begun to be recognized by many as a Profes sional discipline, its roots are deep in history. This brief historical review will attempt to inform the reader of some of the thinking and writing concerning Pastoral Counseling since its beginning.

Pastoral Counseling appears to have been born as a result of Christ's example and teaching. His instructions to minister to individual needs gives direct authority to the Pastor to counsel, if that is the need. Coates, $(1959)^{9}$. Pastoral Counseling has therefore, almost always been associated with Christianity, and has not been so widely accepted within Judaism. It is within Protestantism that Pastoral Counseling has received the widest support, although historically it has been a part of Catholicism.

One of the first examples of Pastoral Counseling is found in the Letters of St. Paul The Apostle to the early Church. In those Epistles he counsels them in such areas as marriage and family relationships, divorce, and sexual conflicts. (I Cor. 7$)^{10}$

During the early centuries, called the "age of Church Fathers", two important books were written which dealt with Pastoral Counseling. John Chrystostom wrote Treatise on the Priesthood and Ambrose of 
Milan wrote Three Books on the Duties of the Clergy. Both of these works described the responsibility of the Pastor to counsel (Oates, $1959)^{11}$.

As the clergy-laity roles become more distinct, the one-to-one ministry was severely hindered, and save for the confessional, there was almost no individualization between the priest and his parishioneers. This lapse in Pastoral Counseling lasted throughout mediaeval Chris tianity. During the middle ages the parish priest was seen as the most learned man in the community and he was sought out for many things, including counseling.

It was not until the Reformation in the 16 th Century, as Protes tantism separated from the Roman Catholic Church, that Pastoral Counseling began to take on real importance. Luther's book Letters of Spiritual Counsel linked physical health with Spiritual health and he felt that the Pastor's home visits were as important as those of the Physician (Oates, 1959) ${ }^{12}$. Martin Bucer wrote that preaching was not enough, and that people needed individual guidance. The chief result of this reformation period for Pastoral Counseling was the abandonment of the confessional as a Sacrament, and the emergence of a Pastoral pastor.

During the 17th Century of Puritanism in England, the emphasis on Catachizing, or public and private teaching, put more attention on the pastor as a Counselor. Some of the modern procedures which they 
utilized in their counseling included listening, empathy, keeping confidences, non-judgmental acceptance, and quiet optimism (Oates, $1959)^{13}$.

There is little written or known about Pastoral Counseling in the 18th Century, but by the 19th Century it was gaining acceptance in America. A minister named Horace Bushell wrote a book called Christian Nurture in which he stressed the personality formation in the infant and the need for a proper environment. He was one of the first ministers to have time specifically set aside for Counseling, and one evening each week was spent at the Church office for that purpose. Washington Gladden described the Pastor as above all a friend, and reemphasized the close relationship of mental and physical health.

Two events which marked the end of the 19th Century were the introduction of the Psychology of Religion and the development of Clinical Pastoral Training.

In 1899 the first course called the "Psychology of Religion" was offered at the Hartford Theological Seminary, and many schools soon followed. By the 1930's there was wide-spread interest in Frued and Psychiatry. Although the church reacted violently against Fruedian thinking and its emphasis on sex as the central motivating emotional impulse (Arbuckle, 1968) ${ }^{14}$, the literature on the Psychology of Religion began giving special attention to individual counseling. 
In 1938, John Bonnell published Pastoral Psychiatry, which was one of the first books giving exclusive attention to the work of the Pas tor as Counselor. Rollo May's book in 1939 called The Art of Counseling was the first systematic study of Counseling, and is still popular among Counselors today.

Perhaps the most valuable single influence in enabling the present day pastor to function effectively as a Counselor, was the initiation of Clinical Pastoral Training. Anton T. Boisen fathered this movement which placed pastors in Supervised Counseling settings, such as hospitals and prisons. The program demanded that the Pastor Counselor accept the same disciplines required of those in other Counseling professions, and gave them first hand experience in dealing with those in need. The key element was adequate supervision, and on the job experience. It was the first time that ministers could experience various problem situations and develop their own approach and style while being supervised by experienced Counselors. This kind of supervised fieldwork experience is utilized now by almost all schools which train Counselors.

The first class in clinical training finished in 1925 from a Chaplaincy Program at the Worchester State Hospital in Massachusetts (Oates, 1959) ${ }^{15}$. It was Boisen's belief that the success or failure of the Pastoral Counselor depended on the extent to which he could bring 
the skills and insights gained from related fields under the control of his basic identity as a man of God.

Relating Pastoral Counseling to other disciplines is also helpful in clarifying what it is and what it is not.

Similarities and Differences between Pastoral Counseling and Other Kinds of Counseling

Almost all of the authors on Pastoral Counseling compare it to other kinds of Counseling. These comparisons generally emphasize the differences and uniqueness of Pastoral Counseling. As stated earlier, Hiltner (1961) 16 was one of the few who saw the processes involved in Pastoral Counseling as basically the same as those in all Counseling. Those processes included accepting, understanding and clarifying the inner conflicts of the troubled individual, and developing a sense of trust so that the client can eventually tell the Counselor that which he has not been able to tell himself. Although Hiltner does not elaborate, it is believed that what he described is called "insight" by other Counselors. To him if there is no relationship to the basic principles and processes used by other professional helpers, then the very term Pastoral Counseling would be an anomaly. He believes the basic difference is not in process but in context $(1961)^{17}$. The Pastor represents a concerned religious community. His setting for counseling is usually the Church (symbolic or real), and everything for which it stands. Because of this context, the ministers come into the Counseling 
session as a representative of God and relates to people on the basis of that representation.

Oden $(1966)^{18}$ states that in psycho-therapy there is an implicit assumption that the client is accepted by the Therapist. The Minister makes this assumption explicit by stating in word or action that God has revealed himself as One who accepts people unconditionally, and it is therefore the Minister's responsibility to do so.

Other writers feel that Pastoral Counseling is not only unique in cont ext, but in goal as well. Faber $(1962)^{19}$ states that while Carl Rogers wants to help people to help themselves or become themselves, the Pastor also wants to help them find the right relationship with God. This may not happen until the person "finds himself", but the selfawareness is only a means to Spiritual awareness. Paul Tillich, , has described this relationship as a helping encounter in the dimension of ultimate concern. Clinebell $(1966)^{20}$. Another uniqueness in Pastoral Counseling is found in the PreCounseling situation. Hiltner $(1964)^{21}$ talks about the prospective or anticipatory aspect which is built into the Pastor's role as "Shepherd of his flock". Clinebell $(1966)^{22}$ speaks of the same thing as he states, that within the Church setting, the Pastor is more able to identify problems early, initiate contact, and prevent crisis. Hiltner $(1961)^{23}$ further states that the counseling "relationship" is generally not the first or last place that the Pastor and the client relate. Therefore, the Minister 
does not begin from scratch, but instead creates out of a previous relationship a special and temporary relationship.

Moser $(1962)^{24}$ lists five distinctions or special aspects of the Pastoral Counselor.

1. His responsibility to the total group limits the amount of time he can spend with any one individual.

2. His right to choose or select his Counselees is limited.

3. He is less free to terminate with individuals as they usually remain a part of the congregation.

4. He functions in a larger religious framework.

5. He often deals with problems which are not severe enough nor appropriate for traditional mental health specialists.

Clinebell $(1966)^{25}$ believes another uniqueness can be seen in the techniques or resources that Pastoral Counseling utilizes. In addition to the use of Scripture, Sacraments, and Prayer, the time tested Wisdom of his traditions are a vital religious tool. Wise $(1951)^{26}$ divides these resources into the tangible and intangible. The tangibles, such as the use of the Bible, Prayer, and religious rites are used primarily for education, support and inspiration. The intangible resources are the religious attitudes and feelings, of the pastor, and the quality of relationship which he can theoretically offer because of the inner qualities of his own life. The value of the tangible resources are largely dependent upon how well the intangibles are communicated within the relationship. 
Another assumed difference between Pastoral Counseling and other kinds of counseling, and one to which this study was especially directed, is that of the training which is involved. For the Minister, some kind of formal education is required by the Church. A Bachelor's Degree is usually received at a Bible, Religious, or Church related College, and often a 2 or 3 year graduate degree is obtained at a Seminary.

The stated purpose of Northwest Christian College is "to secure, teach, train and search out consecrated men and women. . to preach and practice the pure New Testament Gospel. . as exsmplified in the (early Church)" and to stand for the Biblical Doctrine of the Diety of Christ. - and Supreme Authority of the Holy Scriptures. . " (1972). Because of these goals, the curriculum at NCC is directed mainly toward understanding the Bible and Christian or Religious education. This accounts for well over half of the 186 term hours required for ministerial students. The remaining hours are in liberal arts, the sciences, and speech. There are very few psychology or counseling courses offered, and no counseling courses are required for graduation.

For many Ministers additional education is received at Graduate School. Seventy one percent of the ministers in this study had at least attended, if not graduated from, a Seminary. Seminaries usually offer a more complete Counseling program and many belong to the Association for Clinical Pastoral Education. This association is an outgrowth 
of the work done by Anton T. Boisen 50 years ago, and as stated earlier, brings Theological students into supervised encounters with problemed individuals or groups. This formalized program is presently available only on the graduate level, but even there it is usually an elective, and not necessary for graduation.

Unlike counseling specialists in other disciplines, who must concentrate their education solely on Counseling training, the Minister must receive training which prepares him for many tasks within the Church. Counseling skills are generally not stressed unless the ministerial student chooses to specialize in Counseling.

However, this should not mean that Counseling skills are unimportant to the Minister. As Clinebell $(1966)^{28}$ has so aptly stated: "The Pastor regardless of his training, does not enjoy the privilege of electing whether or not he will counsel or not counsel with his people... his choice is not between counseling or not counseling, but between counseling in a disciplined and stilled way and counseling in an undis-. ciplined and unstilled way".

Tweedie $(1963)^{29}$ sums up the similarities and differences between Pastoral Counseling and other kinds of counseling. "Pastoral Counseling does not attempt to substitute piety for professional competence nor mistake sterile secular solutions for the real answers to Spiritual needs. It is a Therapy which starts from the fact that it has behind it the Healing Power of Christ, which envisions every Psychopath 
as a potential Christian and which over and above its processes of reconciling, conscious and unconscious; never loses sight of its purpose of leading a man's soul nearer to God. It can never fall into either of the two errors already named. It has far too much reverence for the dignity and the integrity. of man ever to descend to the level of the bungling amateur, and it has far too much sensitiveness to the voice of God, ever to let its Science be earthbound". 
CHAPTER III

\section{METHODOLOGY}

\section{SELECTION OF SAMPLE}

When plans for this study were initiated early in 1972, it was thought that it would be directed to a sample of all of the Christian Church and Church of Christ ministers in Oregon who had graduated from Northwest Christian College. Information received from NCC indicated that there were 170 separate congregations in Oregon staffed by a total of 200 ministers. One hundred thirty one of these ministers were said to be NCC graduates. It was decided that individual interviews would be given to 15 to 20 percent of this total. Upon limiting the population to only full-time, senior ministers (who graduated from NCC), the total was reduced to 86 . Because of this relatively small number, it was determined to contact the whole population. The thinking was that if the whole population was contacted the results would be more valid and reliable than if a random sample was selected. How ever, time and travel limitations made individual interviews of all the ministers prohibitive, and a questionnaire was prepared.

\section{Selection of Measuring Instrument}

It was decided that the questionnaires would be mailed to the ministers with instructions to be completed and returned. Much attempt 
was made to create a questionnaire which would be clear enough and short enough so that the ministers would take the time to participate. It was made almost entirely closed ended for this purpose and care was taken to allow for a variety of responses. A preliminary questionnaire was tested on four ministers, along with an interview, to evaluate the measuring instrument. Dr. Bixler, from NCC, was also contacted regarding the initial questionnaire. On the basis of the preliminary testing and evaluating appropriate revisions were made and a final questionnaire was prepared and reproduced.

\section{Collection of Data}

The final questionnaire, along with an enclosed letter, (Appendix A and B) was mailed with a stamped, self-addressed envelope to each of the 86 ministers on January 1, 1973. Although the questionnaires were to remain anonymous, the envelopes were each coded so that follow-up phone calls could be made to those ministers who did not return their questionnaire. After one month 57 questionnaires had been returned. Six of those could not be used as they did not meet the population specifications. Follow-up phone calls were made to as many of the remaining ministers as could be contacted, and another 10 useable questionnaires were returned. This provided 61 useable questionnaires from a revised population of 80 , or a 76 percent return. 


\section{Data Processing}

Data on the returned questionnaires was transferred to a Fortran Coding Form and IBM Cards were key punched at the Portland State University Computer Center. Each card, with 73 columns or responses represented one questionnaire. A talley program was run on the cards at the Computer Center and the frequency and percentage distribution for each response was listed on the print-out. A cross-tab program was also run which correlated selected questions with each other showing if they were related or independent of each other. 


\section{CHAPTER IV}

\section{PRESENTATION AND INTERPRETATION OF DATA}

In this section the results of the study have been discussed question by question with each possible response listed and explained. A frequency and percentage domination was shown for each question and correlations among certain responses have been made where it was felt applicable.

Years in Present Ministry

Two-thirds of the ministers had been at their present church for less than 6 years. That supported the belief held by many, that ministers are very mobile and seldom stay longer than 5 years in any one church. It was assumed that if the minister remained in one church for several years, he would grow increasingly more familiar with the individuals there, and perhaps spend an increasing amount of time involved in Coun-. seling. The results showed, however, that there was no positive relationship between the length of time in the same church and the amount of time spent in Counseling. There was also no relationship shown between the time variable and the number of times that a specific individual was seen for Counseling. 


\section{TABLE I}

\section{FREQUENCY AND PERCENTAGE DISTRIBUTION}

OF THE NUMBER OF YEARS IN THE

MINISTER'S CURREN'T

MINISTRY :

$\begin{array}{lccccccc}\text { Years in Present Ministry } & 1-2 & 3-5 & 6-9 & 10-15 & \begin{array}{c}\text { Over } \\ 15\end{array} & \begin{array}{c}\text { No } \\ \text { Answer }\end{array} \\ \text { a. No. of Responses } & 19 & 22 & 12 & 7 & 1 & 0 \\ \text { b. Percent of Total* } & 31 \% & 36 \% & 19 \% & 11 \% & 1 \% & 0 \%\end{array}$

*The Percentages used have been rounded off to the nearest whole number and may not total exactly 100

\section{Membership of Church}

The size of the church where the minister was employed was anywhere from under 75 to over 350 members. It was expected that the size of the church would dictate the Counseling patterns to a large extent, and the size did directly affect the amount of time spent in Counseling. Over 80 percent of the ministers from the largest churches spent more than 6 hours per week Counseling, while about the same percentage from the smallest churches spent less than 5 hours per week in Counseling. Few relationships were found, however, between size and other variables. It was expected that church size might be related to the kinds of problems seen or the procedures used, and some correlations were found. It only seemed appropriate that as the number of people in the church increased so should the Counseling demands and the amount of time spent in Counseling. 
TABLE II

\section{FREQUENCY AND PERCENT AGE DISTRIBUTION \\ OF THE SIZE OF THE \\ CHURCH}

\begin{tabular}{lccccccc} 
Membership of Church & $25-75$ & $76-150$ & $151-250$ & $251-350$ & 350 & Ans. \\
\hline a. No. of Responses & 7 & 16 & 13 & 11 & 14 & 0 \\
b. Percent of Total & $11 \%$ & $26 \%$ & $21 \%$ & $18 \%$ & $22 \%$ & $0 \%$
\end{tabular}

Size of Town Served

The size of the town or city in which the minister was located was also varied, with about the same number coming from towns under 5,000 as those from towns over 10,000. The size of the town did not necessarily determine the size of the church as approximately only half of the smallest and largest churches were located in the smallest and largest towns. It was thought a larger town would provide for more referral resources and would therefore utilize them more. However, results showed there was no relationship. Although a large town might. be considered to breed more social deviency, such as the use of alcohol and drugs, it was not found to be a cause for Counseling more than in smaller towns. It appeared that the kind of counseling that was done by the ministers was more due to individual than corporate differences. 
TABLE III

THE FREQUENCY AND PERCENTAGE

DISTRIBUTION OF THE SIZE

OF THE TOWN

SER VED

\begin{tabular}{lccccccr} 
Size of Town Served & $\begin{array}{l}100- \\
1,000\end{array}$ & 5,000 & 10,000 & 20,000 & 20,000 & Answ \\
\hline a. No. of Responses & 9 & 17 & 10 & 8 & 16 & 0 \\
b. Percent of Total & $14 \%$ & $27 \%$ & $16 \%$ & $13 \%$ & $26 \%$ & $0 \%$
\end{tabular}

Differentiating Pastoral Counseling from other Kinds of Counseling

As the literature revealed, there were varying thoughts by the ministers as to what Pastoral Counseling was. It was assumed that almost all of the ministers would characterize it in some Spirital or religious manner. The majority did describe it in terms of its relationship to God, its reliance on Faith, and its use of the Bible and Prayer. Only $14 \%$ stated that it did not differ from other kinds of counseling or differed only in "non-Spiritual" terms.

The orientation that the minister had toward counseling closely related to his use of Prayer and Scripture during Counseling sessions. If he saw no difference or only a Secular difference, the chances were 2 to 1 that he utilized prayer or Scripture only rarely. If saw a Spiritual difference, 69 percent utilized Prayer and 59 percent utilized Scripture often or almost always. 
TABLE IV

FREQUENCY AND PERCENTAGE DISTRIBUTION

OF HOW PASTORAL COUNSELING

IS DIFFERENT FROM

OTHER KINDS OF

COUNSELING

No. of Responses Percent of Total

No Difference

Secular Difference

Spiritual Difference

No Answer
4

5

43

9
$6 \%$

$8 \%$

$70 \%$

$14 \%$

Priorities of Pastoral Duties to the Minister, the Board and the Congregation

This question was designed to determine how important, (compared to other duties), Counseling was to the Minister, and how important he felt it was to his Board, (elected governing body within the Church), and his congregation in general. It required the Minister to rank, by priority, six suggested pastoral duties. The results indicated a wide range of thinking as what the priorities are, but the ministers' perception of how the Board and congregation would rank them, closely matched his own ranking. That could have meant that churches hire ministers who think like they do, but it is also possible that the minister projects onto his Board and congregation his own thinking, which could only be determined if both Board and people in the church were polled 
independently of the minister. This illustration shows how often each duty was listed in first, second or third priority.

\section{FIGURE 1}

Top Priorities of the Minister and His Perception of the Priorities of the Board and Congregation

\begin{tabular}{c}
$\%$ \\
\hline 100 \\
95 \\
90 \\
35 \\
80 \\
75 \\
70 \\
65 \\
50 \\
55 \\
50 \\
45 \\
40 \\
35 \\
30 \\
25 \\
20 \\
15 \\
10 \\
5 \\
0
\end{tabular}

70

65

50

55

50

45

40

35

30

25

20

15

10

5

0

X
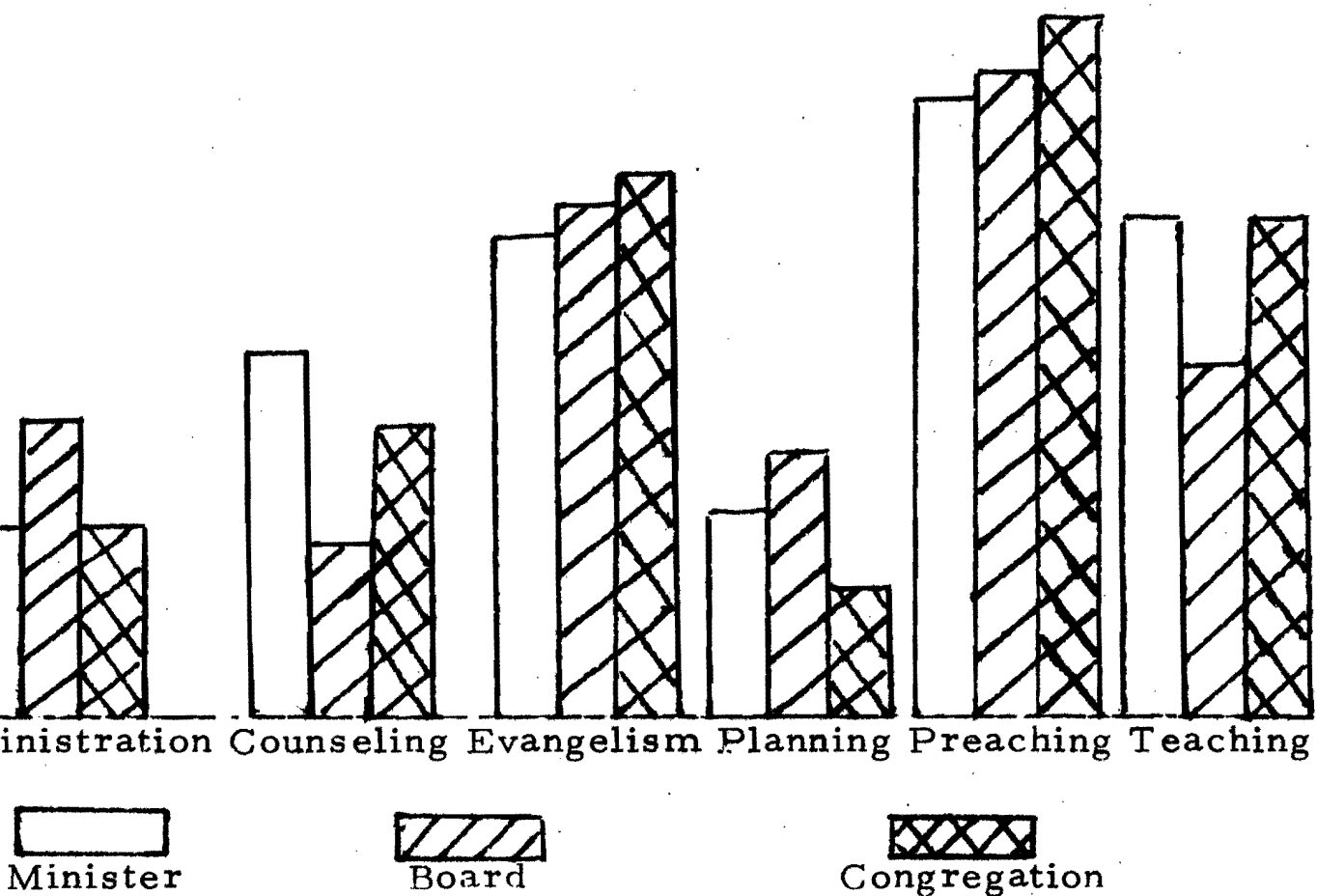

XXX

Congregation

$\%$ who felt it was first, second or third priority. 
It was quite evident that Preaching is considered the most important duty by Minister, Board, and congregation. Most saw Counseling as being of least importance to the board and fourth, out of six, to minister and congregation.

There was no significant correlation between the minister's ranking of counseling and the amount of time spent per week involved in Counseling. That seemed unusual, and indicated that regardless of how important the minister felt counseling was, the counseling demands of the congregation remained fairly constant. There was more relationship between the perceived importance to the congregation and the amount of time spent per week in Counseling. The majority who listed it as low priority to congregation, spent a. low amount of time Counseling, and the majority who listed it as high priority for congregation spent a high amount of time Counseling. It is unknown whether the perceived importance of counseling to the congregation determined the amount of time spent in counseling, or whether more time spent in counseling determined that it was more important to the congregation.

This question revealed a great deal as to what skills the minister needs to have in order to be hired by the board and accepted by the congregation. The minister's Counseling skills must be in conjunction with his skills in preaching, teaching, and evangelizing if he is to keep his job. But the importance of Counseling cannot be dismissed, and the minister's abilities must reflect that importance. 
TABLE V

FREQUENCY AND PERCENTAGE DISTRIBUTION OF THE IMPORTANCE OF COUNSELING TO THE

MINISTER, THE BOARD, AND THE

CONGREGATION

Counseling* Priority \#1 \#2 \#3 \#4 \#5 \#6 \#7 Answer

a. Self

1) No. of Respon$\begin{array}{lllllllllll}\text { ses } & 1 & 8 & 14 & 14 & 8 & 6 & \cdots & 1 & 9\end{array}$

2) Percent of

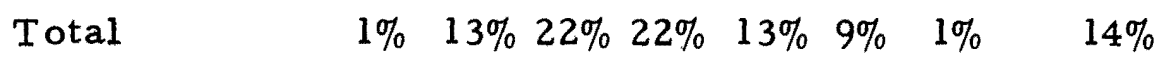

b. Board

1) No. of Responses

$\begin{array}{lllllll}1 & 1 & 8 & 8 & 14 & 15 & 1\end{array}$

13

2) Percent of Total

$\begin{array}{llllllll}1 \% & 1 \% & 13 \% & 13 \% & 22 \% & 24 \% & 1 \%\end{array}$

$21 \%$

c. Congregation

1) No. of Responses 1 $\begin{array}{lll}8 & 9 & 14\end{array}$ 11 $80 \%$ $\quad 14 \%$

* The data on the other pastoral duties is presented in Appendix C.

Average Number of Hours Spent per Week in Counseling

Seventy-five percent of the Ministers spent between 0 and 8 hours per week in Counseling. The average amount of time spent was between 5 and 6 hours per week, or about 15 percent of a 40 hour week. That was half the amount of time found by Eaton $(1963)^{31}$ in a study he made of 34 Suburban Pittsburgh pastors in 1963. He found that 30 percent of their time was spent in Counseling. His study was only of large city churches 
though, and this study more accurately reflects the average time spent in Counseling by a cross-section of ministers from various sized churches and towns.

Fourteen percent of the ministers did not answer the question, primarily because of an inability to compute an average number of hours due to wide weekly differences in Counseling demands. As stated earlier, the time spent in Counseling was generally related to Church size. Virtually all of the ministers who did less than 3 hours of Counseling per week came from churches with under 150 members. Nineteen percent of the ministers utilized over 9 hours per week in Counseling which indicated that Counseling is especially necessary and important to some churches and/or ministers.

\section{TABLE VI}

\section{FREQUENCY AND PERCENTAGE DISTRIBUTION OF THE AMOUNT OF TIME SPENT PER \\ WEEK IN COUNSELING}

\begin{tabular}{lcccccccc} 
& & \multicolumn{1}{c}{ Hours } & \multicolumn{2}{c}{ Over } & No \\
Total Responses & None & $1-2$ & $3-5$ & $6-8$ & $9-11$ & $12-14$ & 15 & Answer \\
\hline No. of Responses & 1 & 8 & 13 & 17 & 6 & 4 & 3 & 9 \\
& &. & & & & & & \\
Percent of Total & $1 \%$ & $13 \%$ & $21 \%$ & $27 \%$ & $9 \%$ & $6 \%$ & $4 \%$ & $14 \%$ \\
& Low & $\begin{array}{c}\text { Med. } \\
\text { Hi. }\end{array}$ & & & & & \\
Answered Responses & $0-5$ & $6-8$ & $9+$ & & & & \\
No. of Responses & 22 & 17 & 13 & & & & \\
Percent of Total & $42 \%$ & $33 \%$ & $25 \%$
\end{tabular}


Problem Areas:

This question was designed to determine how often each of nine suggested problem areas were the primary reason that Counseling was sought or given. Other problem areas listed, besides those suggested, included one mention sach of Community Problems, group and intrapersonal problems.

The illustration below shows the overall results of the question by charting the total percent of respondents who felt each problem area was often or almost always the primary reason Counseling was sought. Each separate response will then be dealt with in detail.

\section{FIGURE 2}

Percentage of Respondents Listing Each Problem Area as Often or almost Always the Reason Counseling

95

was Sought

90

Problem Areas

85

80

75

70

65

60

55

50

45

40

35

30

25

20

15

10

5

0

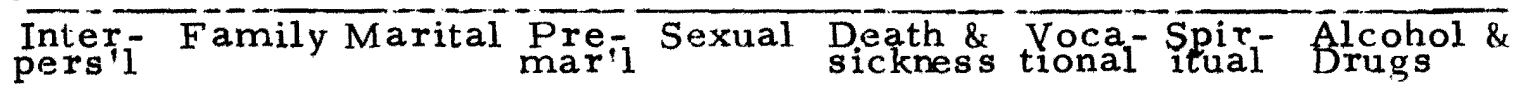


Interpersonal Problems

Individuals sought out Pastoral Counseling for interpersonal problems often or almost always (68 percent) of the time. It was rated as the numberone problem for which counseling was sought almost always, but when "often", and "almost always" a re lumped together, it was fifth in frequency behind Spiritual, Family, Marital, and death and sickness problems. Individuals very often sought out Pastoral Counseling for problems they were having in relationships.

Family Problems (involving at least three people)

The high percentage of people seen for family problems $(78$ percent often or almost always) indicated that ministers spend a great deal of time treating the same kind of problems that bring people into mental health clinics and Family Counseling Services. Only 14 percent stated that they seldom counseled family problems, and no one said that they never did.

\section{Marital Problems}

The same ministers who dealt with family problems a high degree of the time, also came into contact with marital problems. Only five ministers, out of 48 , felt that they counseled maritals less than families. Three thought they saw more maritals than families. That close relationship indicated that if the minister sees one kind of problem, he is likely to see the other also. 
$\underline{\text { Pre-Marital }}$

It was thought that because the minister often performs wedding ceremonies, he would often provide pre-marital counseling for the couple. Fifty-nine percent considered pre-marital counseling as often or almost always the reason counseling was sought. Again it was related to how much time they spent in marital counseling. Ninety-five percent of those who did extensive pre-marital counseling also did extensive marital counseling.

$\underline{\text { Sexual }}$

Counseling regarding sexual problems was seldom or never the primary reason counseling was sought with the majority of the ministers. Perhaps people within the Church were embarrassed to seek out the minister for that problem or the minister may consider it only symtomatic and not the primary reason for counseling. Many ministers never counsel for sexual problems more than any other suggested problem area. It was related to pre-marital problems, however, as twothirds of those dealing with sexual problems frequently saw pre-marital problems. The size of the church and town was also shown to be related to the frequency of this problem area. Ministers from large churches were $2-1 / 2$ times more apt to counsel sexual problems often than ministers from the smallest churches. If the town was over 10,000 , ministers were twice as apt to see this problem often, than those ministers 
from towns under 5,000. This finding indicates that in larger churches or towns sexual problems are more prevalent, more discussed, or more reported by the minister than in smaller churches and towns.

Death and Sickness

Counseling around problems dealing with death and sickness accounted for the fourth most prevalent problem area. This area has been traditionally associated with Pastoral Counseling because of the religious and philosophical questions which surround death. Seventyone percent of the ministers provided counseling in this area extensive1y. Even though it might be suspected that there would be more demand for this kind of counseling in a large church, the results showed there was almost always identical frequency for the largest and smallest churches.

\section{Spritual Problems}

This problem area which is especially associated with Pastoral Counseling accounted for the largest percentage of high frequency counseling. However, only 13 percent felt that it was almost always the reason counseling was sought. Based on much of the literature, such as Arbuckle $(1969)^{32}$, it would be assumed that this problem area would be listed by the majority as almost always the reason that counseling is sought. In fact, the results showed that family problems are only slightly less prevalent than Spiritual problems. Some ministers may 
have believed that the other problems are symptomatic, or the result of Spiritual problems, but it appeared that it was more related to the min isters whole philosophy regarding counseling. Eighty-six percent of the ministers who used Prayer in the Counseling session of a great deal, felt that Spiritual problems were often or almost always the reason counseling was sought.

\section{Vocational Problems}

Vocational related problems are least likely to be referred to the pastor. Only 8 percent considered this problem to be often the reason counseling was sought. That may have indicated that people within the church do not have many vocational problems, or that the minister is seen as ineffective or inappropriate in dealing with job related matters, and therefore not contacted.

\section{Alcohol and Drugs}

Although these are serious social problems, 65 percent reported that they never or seldom deal with them in counseling. It is wondered why, if the minister is seen as an especially trusted person, that more people do not seek out his counseling in this area. Perhaps church people found it difficult to approach the minister regarding deviant behavior. The minister may be viewed as making value judgments and condemning. such behavior. It might have also been possible that individuals within the church are just not as involved in these kinds of activities as much as those outside the church. 
Unexpectedly, no correlation could be made between the size of the church or town and prevalency of this problem area.

\section{TABLE VII}

\section{FREQUENCY AND PERCENT AGE DISTRIBUTION OF \\ THE PRIMARY REASONS PASTORAL \\ COUNSELING IS \\ SOUGHT}

\begin{tabular}{lcc} 
& No & Almost No \\
Problem Areas & Never Seldom Opinion Often Always Answer \\
\hline
\end{tabular}

1. Interpersonal
a. No. of Responses

$0 \quad 9 \cdot 3$
3
32
10
7
b. Percent of Total
$0 \% \quad 14 \%$
$52 \% \quad 16 \%$
$11 \%$

2. Family

$\begin{array}{llclccc}\text { a. No. of Responses } & 0 & 9 & 2 & 41 & 7 & 2 \\ \text { b. Percent of Total } & 0 \% & 14 \% & 3 \% & 67 \% & 11 \% & 3 \%\end{array}$

3. Marital

$\begin{array}{llllrll}\text { a. No. of Responses } & 0 & 12 & 0 & 42 & 4 & 3 \\ \text { b. Percent of Total } & 0 \% & 19 \% & 0 \% & 68 \% & 6 \% & 4 \%\end{array}$

4. Pre-Marital

$\begin{array}{llllrll}\text { a. No. of Responses } & 1 & 19 & 2 & 34 & 3 & 2 \\ \text { b. Percent of Total } & 1 \% & 31 \% & 3 \% & 55 \% & 4 \% & 3 \%\end{array}$

5. Sexual

$\begin{array}{lcllrll}\text { a. No. of Responses } & 7 & 37 & 1 & 12 & 0 & 4 \\ \text { b. Percent of Total } & 11 \% & 60 \% & 1 \% & 19 \% & 0 \% & 6 \%\end{array}$

6. Death in Sickness

$\begin{array}{llllrll}\text { a. No. of Responses } & 0 & 15 & 0 & 39 & 5 & 2 \\ \text { b. Percent of Total } & 0 \% & 24 \% & 0 \% & 64 \% & 7 \% & 3 \%\end{array}$

7. Spiritual
a. No. of Responses
$0 \% \quad 9$
1
42
8
2
b. Percent of Total

$0 \% \quad 13 \%$
$1 \%$
$68 \% \quad 13 \%$
$3 \%$

8. Vocational
a. No, of Responses

$2 \quad 43$
4
5.0
7
b. Percent of Total
$3 \% \quad 70 \%$
$6 \%$

$8 \% \quad 0 \%$
$11 \%$

9. Alcohol or Drugs

\begin{tabular}{llllllc} 
a. No. of Responses & 5 & 35 & 1 & 13 & 0 & 7 \\
b. Percent of Total & $8 \%$ & $57 \%$ & $1 \%$ & $21 \%$ & $0 \%$ & $11 \%$ \\
\hline
\end{tabular}


Procedures used during the Counseling Session

As with the problem areas, pastors were asked to indicate how often they utilized the suggested counseling procedures or techniques during an average counseling session. It was hoped that this would reveal some of what the minister does while he counsels.

The illustration below summarizes the procedures and indicates which ones were used extensively (often or almost always). Each will then be discussed individually.

\section{FIGURE 3}

Most Frequently used Procedures of the Minister During an Average Counseling Session

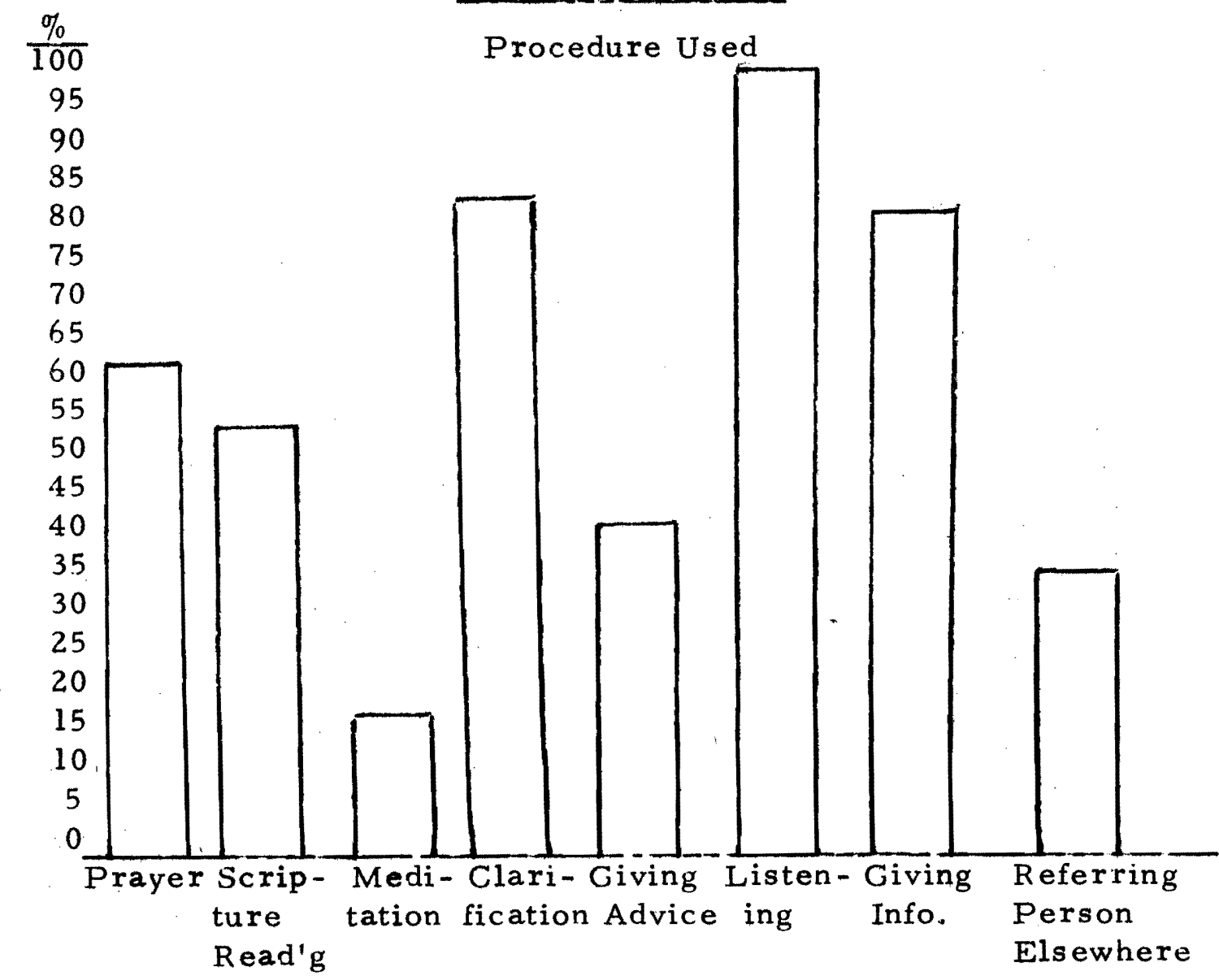

$\%$ who utilized procedure often or almost always 
Prayer

It was expected that the majority of the ministers would indicate that they used prayer during their counseling sessions almost always. That was believed because of the strong emphasis on prayer in the Christian Church and at Northwest Christian College in all areas of the ministry. Also, Tweedie $(1963)^{33}$, Hiltner $(1961)^{34}$, and Wise $(1951)^{35}$, in their books on Pastoral Counseling, stress the importance and legitimacy of prayer and Scripture reading during the counseling session. The results showed, however, that only 20 percent of the ministers used it almost always and 34 percent said they seldom utilized it during counseling.

As stated earlier, the use of Prayer was related to how the minister defined Pastoral Counseling. If the description was in Spiritual terms they were much more likely to utilize the Spiritual resource of Prayer. The use of Prayer was also found to be related to the size of the congregation. Twenty-six percent of the ministers who came from a church of under 150 members used Prayer on a low (never or seldom) frequency basis and 74 percent on a high (often or almost always) frequency basis. If the church had over 250 members, the figures were 54 percent for low usage and 45 percent for high usage. The reason for that may have been because a large church is less personal and more formal and, therefore, may be less likely to use such as "intimate" technique. It was also possible that ministers of larger churches were 
less conservative in their Theology and did not believe in the necessity of Prayer in the counseling session as much as those ministers from smaller churches. The real reason for this phenomenon can only be determined through further research.

$\underline{\text { Scripture Reading }}$

Most of the same assumptions made concerning the use of Prayer, were also made regarding the minister's use of Scripture reading in the counseling session. Because of the evangelical nature of the Christian Church and their emphasis on the Authority of the Bible, it was expected that that Authority would often be brought directly into the Counseling session. Nevertheless, the results showed that only 8 percent utilized Scripture reading almost always, 45 percent often, 33 percent seldom, and 4 percent never utilized it. Although, in general, the Bible was used less than Prayer, the y were both assumed to be Spiritual resources and were found to be closely correlated. Seventy percent of the ministers who utilized Scripture seldom, also seldom utilized Prayer, and 93 percent of those who used Scripture almost always used Prayer often or almost always.

As with the use of Prayer, Scripture reading was found to be related to church size. If the church was under 250 members, about 64 percent of the ministers used Prayer extensively. If the church was over 250 members, 42 percent used it extensively. The same implications made regarding church size and prayer, may be applicable here also. 
Meditation

Paul Tournier (Tweedie, 1966) (T6 $^{36}$ has stated that within Pastoral or Christian Counseling it is important to have a period of quiet communion during which both parties in the Therapy session wait before God for his guidance. It was felt that a time for meditation or Goddirected thinking in the counseling session would also bo a "Spiritual Technique", but less direct than Prayer or Scripture reading. The findings indicated that it was the least used of the three with only 15 percent stating that they used it often or almost always. Forty-five percent used it seldom and 19 percent never practiced it during counseling sessions. Most ministers were evidently not comfortable with this resource or did not believe it to be of value.

It was shown to be significantly related to the use of Prayer, and 90 percent of the ministers who used meditation often also responded to a high frequency use of Prayer. It was not found to be related to the size of the church and it appeared that no variables colild be correlated to this relatively unused procedure.

\section{Clarification}

Although the technique of clarification is used extensively within Social Work and Psychology, it was thought that ministers might not be as familiar with it. The fact that 82 percent practiced it often or almost 
always, second only to listening, indicated that ministers were familiar with the term and utilized it in their counseling.

\section{Giving Advice}

Many professional Counselors avoid advice giving for various reasons. The pastors indicated that 40 percent of them give advice often or almost always. The role of advisor may be built into the minister's job of preaching and teaching, and this advice giving may carry over into the counseling situation.

\section{Listening and Giving Information}

The vast majority indicated that they listened and gave information within the counseling session often or almost always.

\section{Referring Person Els ewhere}

It was anticipated that ministers would seldom utilize the referral process, and transfer people to other counselors or agencies. Ministers have been sometimes accused by other counselors of holding on to their "Cases" even when a referral would be appropriate. The results showed that they were split between seldom and often, with the majority listing that they seldom referred people. Sixteen percent were undecided regarding this question, which may have indicated that they did not usually think about their referral patterns. 
TABLE VIII

\section{FREQUENCY AND PERCENTAGE DISTRIBUTION OF HOW OFTEN IDENTIFIED PROCEDURES ARE}

USED IN AN AVERAGE PASTORAL

COUNSELING SESSION

Procedures

1. Prayer

a. No, of Responses

b. Percent of Total

2. Scripture Reading

a. No. of Responses

b. Percent of Total

3. Meditation
a. No. of Responses

b. Percent of Total

4. Clarification
a. No. of Responses

b. Percent of Total

5. Giving Advice
a. No. of Responses
b. Percent of Total

6. Listening
a. No, of Responses
b. Percent of Total

7. Giving Information
a. No. of Responses
b. Percent of Total

8. Referring Person Els ewhere
a. No. of Responses
$0 \quad 26$
$0 \% \quad 42 \%$
b. Percent of Total

$\begin{array}{lllrlr}12 & 28 & 2 & 9 & 1 & 8 \\ 19 \% & 45 \% & 3 \% & 14 \% & 1 \% & 13 \%\end{array}$

$\begin{array}{lllrlr}0 & 1 & 3 & 26 & 25 & 5 \\ 0 \% & 1 \% & 4 \% & 42 \% & 40 \% & 8 \%\end{array}$

$\begin{array}{lllrlr}3 & 29 & 1 & 22 & 3 & 3 \\ 4 \% & 47 \% & 1 \% & 36 \% & 4 \% & 4 \%\end{array}$

$\begin{array}{lllrlr}0 & 0 & 0 & 7 & 53 & 1 \\ 0 \% & 0 \% & 0 \% & 11 \% & 86 \% & 1 \%\end{array}$

$\begin{array}{lllrlr}0 & 6 & 0 & 36 & 14 & 5 \\ 0 \% & 9 \% & 0 \% & 59 \% & 22 \% & 8 \%\end{array}$

Almost

No

Never Seldom Opinion Often

Always Answer 
Training Received; How Helpful it Was in Preparation For the Role as

\section{Counselor}

This section of the questionnaire dealt with where and when the ministers had received training in counseling and how they evaluated that training.

Year Graduated from Northwest Christian College

The results showed a wide spread in the number of years in which ministers graduated from NCC. Graduation dates fell between 1930 and 1971 with the average being between 1955 and 1959. Sixty-two percent graduated after 1955, which indicated that the majority of the ministers are under 40 years old. NCC has continued to grow over the years and had their largest enrollment ever in 1972-1973. Howe the recent increase in enrollment was not picked up by the survey because many recent graduates have gone directly to Seminary, and have not yet begun their full-time ministry. In 1971 , there were $61 \mathrm{NCC}$ graduates in Seminary, and a study directed at them, would yield additional valuable information regarding the NCC Counseling Program. 
TABLE IX

\section{FREQUENCY AND PERCENTAGE DISTRIBUTION OF THE YEAR GRADUATED FROM \\ NORTHWEST CHRISTIAN \\ COLLEGE}

\begin{tabular}{lcc} 
Year Graduated & $\begin{array}{c}\text { No. of } \\
\text { Responses }\end{array}$ & Percent of Total \\
\hline 1. 1970 or After & 3 & $4 \%$ \\
2. $1965-1969$ & 10 & $16 \%$ \\
3. $1960-1964$ & 9 & $14 \%$ \\
4. $1955-1959$ & 17 & $28 \%$ \\
5. $1950-1954$ & 7 & $11 \%$ \\
6. $1945-1949$ & 5 & $8 \%$ \\
7. $1940-1944$ & 5 & $8 \%$ \\
8. 1939 or Before & 4 & $6 \%$ \\
9. No Answer & 0 & $0 \%$
\end{tabular}

\section{$\underline{\text { Seminary Attended }}$}

Seventy-one percent of the ministers indicated that they had attended a graduate Seminary after finishing at NCC. There were 5 separate Seminaries listed to which at least two NCC graduates had attended. Phillips University in Enid, Oklahoma was the largest attended Seminary with 22 percent of the ministers having gone to school there.

It was assumed that the 29 percent who did not secify a Seminary, received no further education following their graduation from NCC. That 
meant that almost one-third of the ministers in the study received their only Ministerial education, including training in Counseling at NCC. It cannot be assumed, therefore, as some have stated, that NCC just prepares ministers for Seminary. In many cases, the ministers' formal education begins and ends with NCC. That underscores the responsibility that NCC has to adequately prepare ministers in all areas of the ministry, including counseling. In addition, as was stated earlier, going on to Seminary does not guarantee that further Counseling training will be obtained.

\section{TABLE X}

FREQUENCY AND PERCENTAGE DISTRIBUTION OF THE SEMINARY

ATTENDED

No. of

Seminary Responses Percent of Total

1. Butler (later became Christian Theological Seminary 5 $7 \%$

2. Christian Theological Seminary 10 $16 \%$

3. Drake 4 $6 \%$

4. Emmanuel 2 $3 \%$

5. Phillips 14 $22 \%$

6. Others 8 $12 \%$

7. None 8 $13 \%$

8. No Answer 10 $16 \%$ 
Institutes and Seminars Attended

Various institutes and seminars provided many of the ministers with Counseling training after their formal education had ended. Almost all of these training sessions were voluntary, and the minister attended in order to increase his knowledge or skills. Sixty-four percent of the ministers indicated that they had attended some institute or seminar which dealt with the area of Counseling or Human Behavior. Half of those who attended, went to one or more of the following: 1. Basic Youth Conflicts --A week long intensive Seminar held in Portland twice a year by Bill Gothard which applies the Bible to various individual and family conflicts. 2. Family Life Institute--A weekend of lecture and discussion looking from a Christian viewpoint at marital and family problems. It is held at various churches in the Northwest and usually led by Dr. Bixler from NCC, and the Christian Family Institute (CFI). 3. Mental Health Clinics--various length and subject seminars sponsored by local mental health associations. It was expected that more than 24 percent would have taken advantage of Basic Youth Conflicts or Family Life Institute. These Training sessions are geared especially for Christians, and CFI is aimed especially at the Christian Church. One possible reason that these and other resources were not utilized more is that it requires a large segment of time to be taken away from normal ministerial duties. Ministers might have also found the available Seminars to be of no value. The fact that one-third had not indicated attending any 
Continuing Education course, points out again the necessity for NCC to provide an adequate Counseling education while the minister is in school.

TABLE XI

FREQUENCY AND PERCENT AGE DISTRIBU CION

OF INSTITUTES OR SEMINARS

ATTENDED

\begin{tabular}{lcc} 
Institutes or Seminars & $\begin{array}{c}\text { No. of } \\
\text { Responses }\end{array}$ & Percent of Total \\
\hline 1. Basic Youth Conflicts & 11 & $18 \%$ \\
2. Family Life Institute & 4 & $6 \%$ \\
3. Mental Health Clinic & 5 & $8 \%$ \\
4. Others & 20 & $32 \%$ \\
5. None & 1 & $1 \%$ \\
6. No Answer & 20 & $32 \%$ \\
\hline
\end{tabular}

Evaluation of Training - NCC

In preparing them for the role of Pastoral Counselors, the majority (68 percent) of the ministers evaluated NCC as being fairly or very helpful. Six percent felt it was extremely helpful and 16 percent felt it did not help at all. Because much of the Counseling Frogram at NCC is on an elective basis, it is not known which of these ministers made full use of the courses offered, and who took no counseling classes. Despite this obvious limitation, the fact remains that over half of the ministers found that at best, they were only slightly helped at NCC to be Counselors. 
The is sue is raised as to how helpful NCC would like to be in preparing ministers to Counsel. The fact that there has been increased emphasis on counseling in the last 10 years at NCC showed that there has been a greater commitment toward training counselors than ever before. The increased emphasis on counseling in recent years seemed to have had an affect on how ministers evaluated the program. Over 70 percent of the ministers who graduated before 1960 felt that they were not helped or only slightly helped at NCC to be counselors. Just over half of the graduates since 1960 said the same. This difference may also be due, in part, to the fact that if the minister was a recent graduate, he could recall his training at NCC better and relate it more closely to his present attitudes and feelings than the minister who graduated over 15 years ago. In any case, if NCC has really committed itself to giving effective Counseling Training, the findings have indicated that some changes or additions in the curriculum may be needed in order to provide a program which is more helpful in preparing ministers for the role of Counselors. Possible suggestions for change are evaluated later in this paper.

\section{Seminary}

Of the 41 ministers who indicated that they had attended Seminary, 54 percent felt that it was very or extremely helpful in preparing them to become Counselors. Forty-six percent believed it was not helpful or only fairly helpful. Although it showed that even attending Seminary was many times not especially helpful in counseling preparation, the 
assumption that Seminary would be more helpful than NCC, was slightly confirmed. Fifty-four percent rated NCC as not helpful or only fairly helpful to them as counselors, compared to 46 percent who felt the same about Seminary. Thirty-six percent felt NCC was very or extremely helpful, compared to 54 percent who felt the same about Seminary. It was not clear whether the reas on for this was because ministers could specialize in counseling more at Seminary, or because there were more counseling courses and requirements at Seminary. No specific Seminary was found to be more effective than the others, which indicated that no Seminary appreciably stressed counseling more than the others. It may also have been that the ministers were not as satisfied qualitatively with the program at NCC as compared to Seminary.

Institutes and Seminars

As expected the vast majority ( 84 percent) of the ministers who attended one or more Institute or Seminars, felt they were very or extremely helpful. No one attended a Counseling Institute or Seminary which they felt was of no help to them as Counselors. It was anticipated that that would be the case because of the choice involved in attending on-going educational functions. The Minister would not be likely to attend something unless he felt that it would be helpful. It may also indicate that most of the institutes and seminars available to ministers are well done and valuable resources. The religious institutes such as 
Basic Youth Conflicts and Family Life Institute were found to be of great value, but no more than mental health clinic seminars. That indicates that ministers are able to learn a great deal within varying contexts and philosophies.

However, 31 percent did not indicate that they had attended any institute or seminar. Over half of that number also had not attended Seminary, which meant that NCC was the total source of Counseling training for about 18 percent of the ministers. Of that number who received all of their training at NCC, 58 percent felt that it was not helpful. Evidently the majority of the minizters who do not continue their education in any way after graduating from NCC, were especially not satisfied with NCC's Training of them for Counseling. It was not clear why this was the case, but it implied a need for further research to determine how NCC can be more effective in reaching the minister who does not seek out further counseling education. 
TABLE XII

FREQUENCY AND PERCENTAGE DISTRIBUTION OF HOW HELPFUL TRAINING HAS BEEN IN PREPARING

THE MINISTER FOR THE ROLE

OF COUNSELOR

Ex-

Not Fairly No Very tremely No

Training Received at Helpful Helpful Opinion Helpful Helpful Ans.

1. Northwest Christian

College
a. No. of Responses
$10 \quad 24$
2
18
43
b. Percent of Total
$16 \% \quad 38 \%$
$3 \% \quad 36 \%$
$6 \% .4 \%$

2. Seminary

a. No. of Responses

316

0

18

420

b. Percent of Total

(who attended)

c. Percent of Total

$6 \% \quad 40 \% \quad 0 \% \quad 45 \% \quad 9 \%$

(who did not attend)

$32 \%$

3. Institutes or Seminars
a. No. of Responses
0
3
4
20
15
b. Percent of Total
(who attended)
c. Percent of Total
$0 \% \quad 7 \% \quad 9 \% \quad 48 \% \quad 36 \%$
(who did not attend)

19

\section{Suggestions regarding the NCC Counseling Program}

After evaluating NCC in terms of how helpful it was in preparing them to be Counselors, the ministers were asked to rate, by degree of agreement, various suggestions regarding the NCC Counseling Program. It was felt that this would reveal specific strengths or weaknesses within the program. Because of unfamiliarity with the current Counseling Program at NCC, many of the ministers did not feel knowledgeable enough to respond, and either left the question blank or checked "no opinion". 
FIGURE 4

A Percentage Distribution of the Number of Ministers Who Agreed and Disagreed with Various Suggestions Regarding the NCC Counseling

Program

\section{Listed Suggestions}

$\frac{\%}{100}$

Agree

Disagree
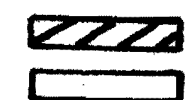

95

90

85

80

75

70

65

60

55

50

45

40

35

30

25

20

15

10

5

0
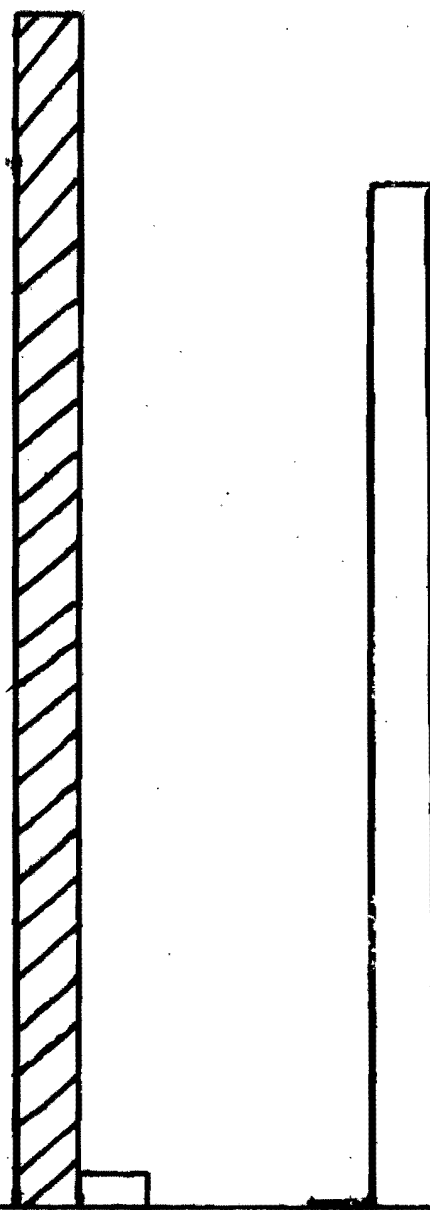

No Change Add more Add more Have Super- Have Fewer

necessary

counseling Psych. vised coun- counseling courses courses seling exp. courses

Make more counseling courses mandatory 


\section{No Change Necessary}

This suggestion was made in order to determine how satisfied the ministers were with the present NCC Counseling program, or the one which they remembered. It was felt that whether the ministers were helped by the counseling program at NCC or not, that, in itself, did not necessarily indicate if they were satisfied with it or not. The results showed that 14 percent agreed with the statement, or felt that change was not necessary, and 43 percent disagreed, or wanted change. Seventy five percent of those who wanted change had received, at most, only a fair amount of help from NCC in becoming a Counselor. That showed that there was a positive correlation between perceivec helpfulness and satisfaction with the program. If they were not helped very much, they were more likely to want changes in the program. In other words, most ministers wanted to be helped more.

When this question was related to the year in which the minister graduated from NCC, the findings indicated that 75 percent of those who graduated after 1960 disagreed, or believed that there should be changes. Forty-two percent of those who graduated between 1950 and 1959 , and 30 percent of those who graduated before 1950, believed the same. Therefore, it was the most recent graduates who were not content with the status quo. That was just the reverse of how helpful the ministers believed NCC had been in preparing them as Counselors. With that question, it was the recent graduates who indicated that they had received 
more help than the earlier graduates had indicated. It was not clearly understood why graduates within the last 13 years felt that NCC was more helpful, and at the same time felt it needed more changes than those ministers who had graduated earlier. It may have indicated that although the Counseling Program had been emphasized more in the last few years, and theoretically become more helpful than before, yourger ministers want a larger or a different kind of program. This increased interest in Counseling parallels the increased popularity in Counseling seen in all of the helping professions.

\section{Add More Clinical Counseling Courses}

This suggestion would have increased the number of Counseling Courses offered within the Counseling Program at NCC, Fifty-five percent agreed that there should be an increase and 12 percent felt there should not be an increase. The findings did not show what kind of Clinical counseling courses the ministers wanted, only that they wanted more courses available. It was not shown how many of the ministers took all of the courses that were offered, but last year only about 7 percent of the student body was enrolled in the Advanced Counseling Seminar. It is not known why the enrollment was so limited, but the study seemed to clearly indicate that the ministers wanted more counseling courses and opportunities to take them.

Add More Psychology Courses

The ministers were not as sure about Psychology Courses as they 
were about Counseling courses. Only 35 percent stated that they agreed, while 12 percent disagreed that there should be more Psychology courses. The remaining 45 percent was uncommitted. For some time, NCC has required a two term course in the Introduction to Psychology and offered one or two Psychology electives. The results showed that the ministers had more mixed feelings about Psychology than any other suggestion. This may have indicated that the ministers want more training in Counseling skills than in Psychological insights. Also, because all of the ministers had taken the required Psychology course, they may have felt more courses were not necessary. Most ministers who stated their disagreement with the suggestion were also opposed to further counseling courses, and were generally satisfied with the program the way it was.

Have Supervised Counseling Experience

An assumption made at the beginning of this study, was that ministers would find practical, supervised counseling experiences valuable in helping them to become counselors, just as Anton T. Boisen had discovered 50 years ago. The assumption was overwhelmingly supported. Seventy-four percent agreed with the suggestion, and half of those agreed strongly. Only one minister did not agree that there should be Supervised Counseling experiences available at NCC. That one minister was satisfied with the counseling program the way it was, and opposed any suggestions for change. Interestingly, he stated that NCC had not been of 
any help to him in the area of Counseling. Even ministers who were unsure about other suggestions, agreed with this one. Ps with the first suggestion, this was also related to the year the minister graduated from NCC. Over 90 percent of the graduates since 1960 agreed that this experience should be available. Although graduates before 1950 did not indicate disagreement, only 47 percent were in agreement. The results made it very clear that ministers would like to see some on-the-job, supervised experience in counseling available at NCC before graduating into the full-time ministry, with its counseling demands.

\section{Have Fewer Counseling Courses}

This suggestion was designed to measure opposite feelings regarding the NCC Counseling program. If the minister felt that the program was already overweighted with courses, it provided an opportunity for him to indicate that feeling. However, virtually no one agreed that there should be a reduction in Counseling courses.

Make More Couns eling Courses Mandatory for Graduation

Because there were no counseling courses required for graduation at NCC, this suggestion was designed to measure how willing ministers would have been to have had counseling requirements. It was expected that while the minister was in school, the importance of learning to be a Counselor might seem relatively insignificant, and recognized only after he graduated, and became involved in Counseling within the Church. 
A mandatory Counseling Course, or courses, would place more responsibility on the school to teach students what they need to know, and want to know later. The results showed that 41 percent agreed with the

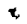

statement, and only 14 percent disagreed. Whether the minister felt

NCC had been helpful or not helpful in preparing him for counseling, most believed that counseling courses should be required. The ministers were willing to make counseling courses mandatcry for graduation in order to be better. Counselors. That indicated some commitment to Counseling education. 
TABLE XIII

FREQUENCY AND PERCENT AGE DISTRIBUTION ON LEVEL OF AGREEMENT REGARDING SUGGESTIONS

FOR THE NCC COUNSELING .

PROGRAM

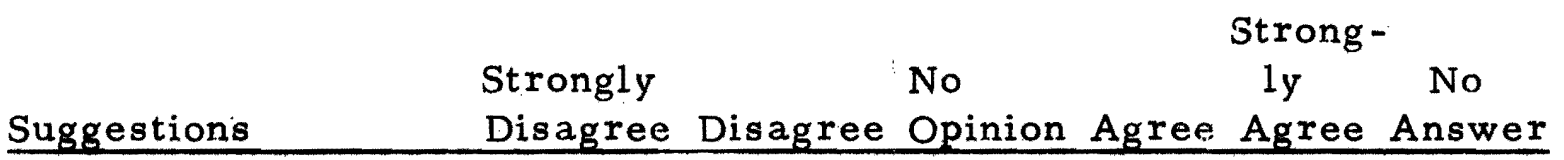

1. No Change

Necessary

a. No. of Respon-

$\begin{array}{ccccccl}\text { ses } & 8 & 19 & 12 & 6 & 2 & 12 \\ \text { Percent of Total } & 12 \% & 31 \% & 22 \% & 11 \% & 3 \% & 19 \%\end{array}$

2. Add More Counseling Courses
a. No. of Respon-
ses 3
b. Percent of Total $4 \%$
5
10
23
$16 \%$
$37 \%$
119
$8 \%$

$16 \%$

3. Add More Psychology Courses

a. No. of Responses

b. Percent of Total

$1 \%$

10

$16 \%$

$\begin{array}{rl}19 & 19 \\ 31 \% & 31 \%\end{array}$

39

$4 \% \quad 14 \%$

4. Have Supervised

Couns eling
a. No. of Respon-
ses
0
$0 \%$
1
$1 \%$
$\begin{array}{rl}7 & 20 \\ 11 \% & 32 \%\end{array}$
26
7
b. Percent of Total
$42 \% \quad 11 \%$

5. Have Fewer Counseling Courses
a. No. of Responses

20

b. Percent of Total

$32 \%$

20

12

0

$0 \quad 9$

$32 \%$

$19 \%$

$0 \%$

$0 \% \quad 14 \%$

6. Make More Counseling Courses Mandatory for graduates
a. No. of Responses
$1 \%$
8
$13 \%$
15
$24 \%$
19
$30 \%$
$7 \quad 10$
b. Percent of Total

$1 \%$

$3 \%$
$11 \% \quad 17 \%$ 
Who Initiates the Couns eling Process

It was thought important to know how the minister got involved in a Counseling relationship. Results of this question and where the ministers referred "cases", would indicate the flow of people to and from the minister. The illustration below shows the distribution of sources that often or almost always initiate the Counseling Process.

FIGURE 5

\section{A Percentage Distribution of Sources that Often or almost Always}

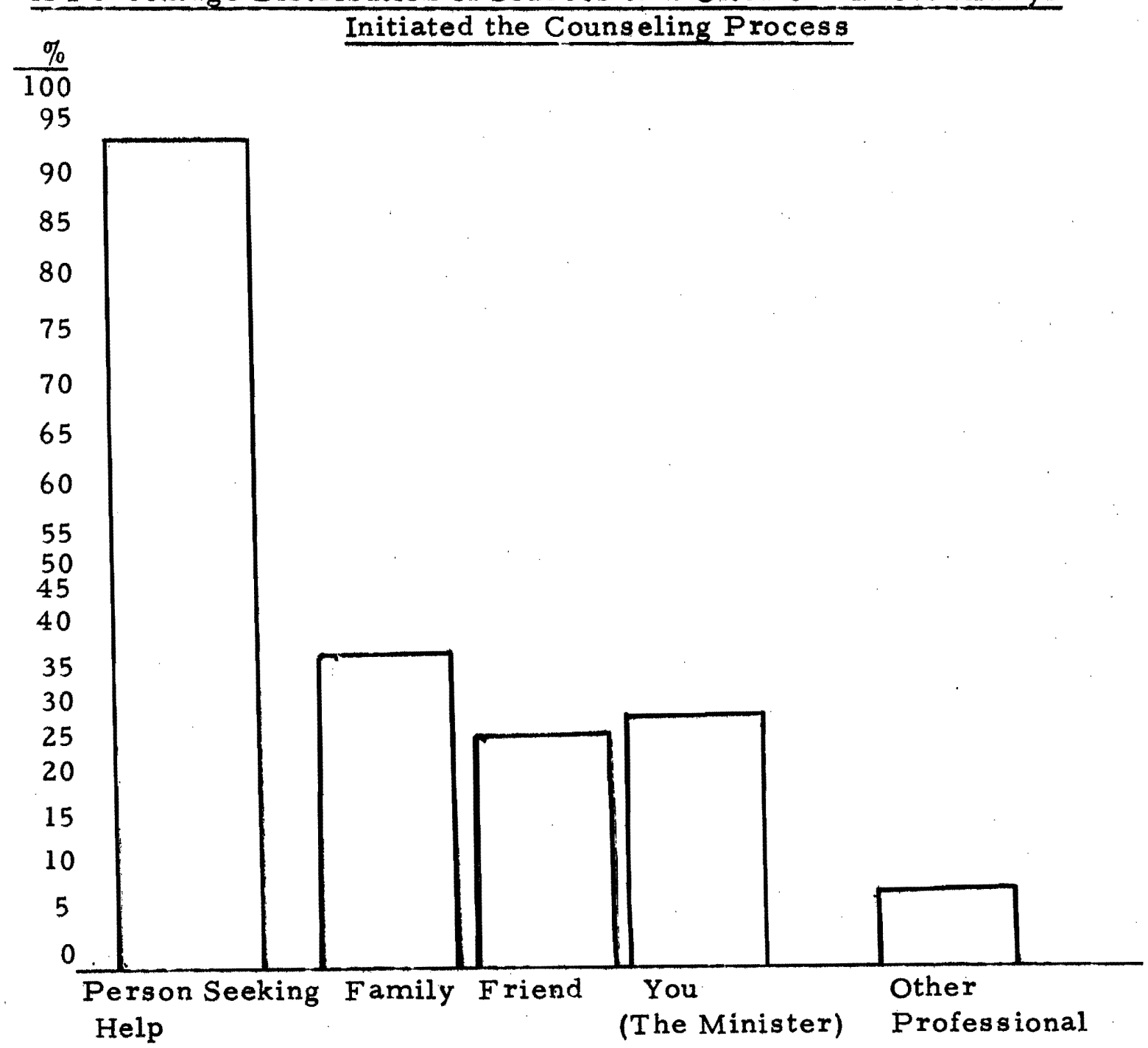


Person Seeking Help

The results showed that 93 percent felt that the person seeking help often or almost always initiated the contact for Pastoral Counseling. The minister was, therefore, viewed as a person who could be, and was, often approached by people who needed Counseling. The findings indicated that the minister was seen as a Counselor to people within the congregation, and related to as such when the need arose. Whether the minister wanted to counsel or not, it appeared that counseling demands were often made upon him.

\section{Family-Friend}

Thirty-six percent felt that the family often, or almost always, initiated the Counseling process, and 25 percent said that a friend of the troubled person often suggested that the minister see that person for counseling. The involvement of these "collateral" pecple in the referral process, showed that other people, besides the counselee, sought out the minister and directed him to individuals or families with problems. The minister was seen as a resource person that family and friend could call upon; concerning people for whom they were concerned.

\section{You (The Minister)}

Only three ministers stated that they never initiated the counseling process themselves. The remaining said that upon occasion, the first counseling contact with an individual or family was made by them. 
It was expected that if a minister remained in the same church for several years, he would be able to recognize potential problems and be comfortable enough to make the initial counseling contact. The results supported that assumption. If the minister was in the church for less than 6 years, he was much less likely to initiate counseling himself, than if he had been in the same church for over 10 years.

\section{Other Professional}

Only 6 percent often received referrals from other professionals, while the majority never or seldom did. That seemed to have indicated that, although the minister was viewed as a counselor by people within, or related to the church, other professional people within the community did not utilize him as a counselor. It was also found that few referrals were made from the minister to other professionals. These facts suggested that there was little cross-over between Pastoral Counseling and other kinds of counseling, and indicates that ministers are fairly separated from other professionals and resources within the community. 
TABLE XIV

FREQUENCY AND PERCENTAGE DISTRIBU'IION

OF WHO INITIATES THE COUNSELING

PROCESS

Occas -

Almost No

Source

Never Seldom sionally Often Always Answer

1. Person Seeking

Help
a. No, of Respon-
ses
b. Percent of Total

$0 \quad 2$
$3 \quad 23$
33
0
$0 \% \quad 3 \%$
$4 \% \quad 39 \%$
$54 \%$
$0 \%$

2. Family
a. No. of Respon- ses

$1 \quad 14$
2320
3
0
b. Percent of Total
$1 \% \quad 22 \%$
$37 \% \quad 32 \%$
$4 \%$
$0 \%$

3. Friend
a. No. of Respon -
$1 \quad 17$
26
15
1
1
b. Percent of Total
$1 \%$
$27 \%$
$42 \%$
$24 \%$
$1 \%$
$1 \%$

4. You (The Minister)

a. No. of Respon -
b. Percent of Total

$3 \quad 27$
$44 \%$
$13 \quad 16$
0
2
$4 \%$
$21 \% \quad 26 \%$
$0 \%$
$3 \%$

5. Other Professional
a. No. of Respon-
ses
b. Percent of Total
$9 \quad 26$
15.4
0
$24 \% \quad 6 \%$
$0 \% \quad 11 \%$

Average Number of Counseling Sessions per Contact

This question was asked to determine how involved, quantitatively, that ministers got with any one individual or family in a counseling relationship. It was expected that ministers used very short term 
treatment, because either the problems they dealt with did not require extended treatment, or because the minister was not prepared to counsel people over long periods of time. The results clearly showed that most ministers did utilize very short term treatment. Forty-seven percent averaged less than 7 sessions. Only 6 percent averaged 7 to 10 sessions, which was similar to the planned short term treatment utilized by many mental health and counseling agencies.- It was not clear why the majority spent so few sessions with their counselees. It may have been a function of time available for counseling. All of the ministers who averaged over 6 sessions per contact, spent over 8 hours per week in counseling, which was more time than the average minister spent. By keeping the number of sessions down, (the average was 3-1/2 per person), less time was required to be spent in counseling. Ninety percent of those who spent less than 3 hours per week in counseling, averaged less than 4 sessions per contact. Other factors involved in this question were not determined, and further study is required regarding the ministers philosophy of counseling relationships. 
TABLE XV

FREQUENCY AND PERCENTAGE DISTRIBUTION OF

THE AVERAGE NUMBER OF COUNSELINC;

SESSION WITH ANY ONE

INDIVIDUAL OR

FAMILY

Number of Sessione

\begin{tabular}{cccccc}
\hline 1 & $2-3$ & $4-6$ & $7-10$ & Over 10 & No Ans \\
1 & 29 & 24 & 4 & 0 & 3 \\
$1 \%$ & $46 \%$ & $39 \%$ & $6 \%$ & $0 \%$ & $4 \%$ \\
\hline
\end{tabular}

\section{Ministers Use of Referral Sources}

The other half of the referral process was where ministers send people when they feel that a transfer is appropriate. A.s stated earlier, 32 percent stated that they often referred people, who came to them for counseling, elsewhere. This question showed how often the referrals were made to 4 suggested referral sources. The illustration below shows the percentage of medium and high frequency use of 4 resources. 
FIGURE 6

Percentage Distribution of Occasionally or Often Used Referral

Resources

$\frac{\%}{100}$

Resource

95

90

85

80

75

70

65

60

55

50

45

40

35

30

25

20

15

10

5

0

Mental Health

Clinic
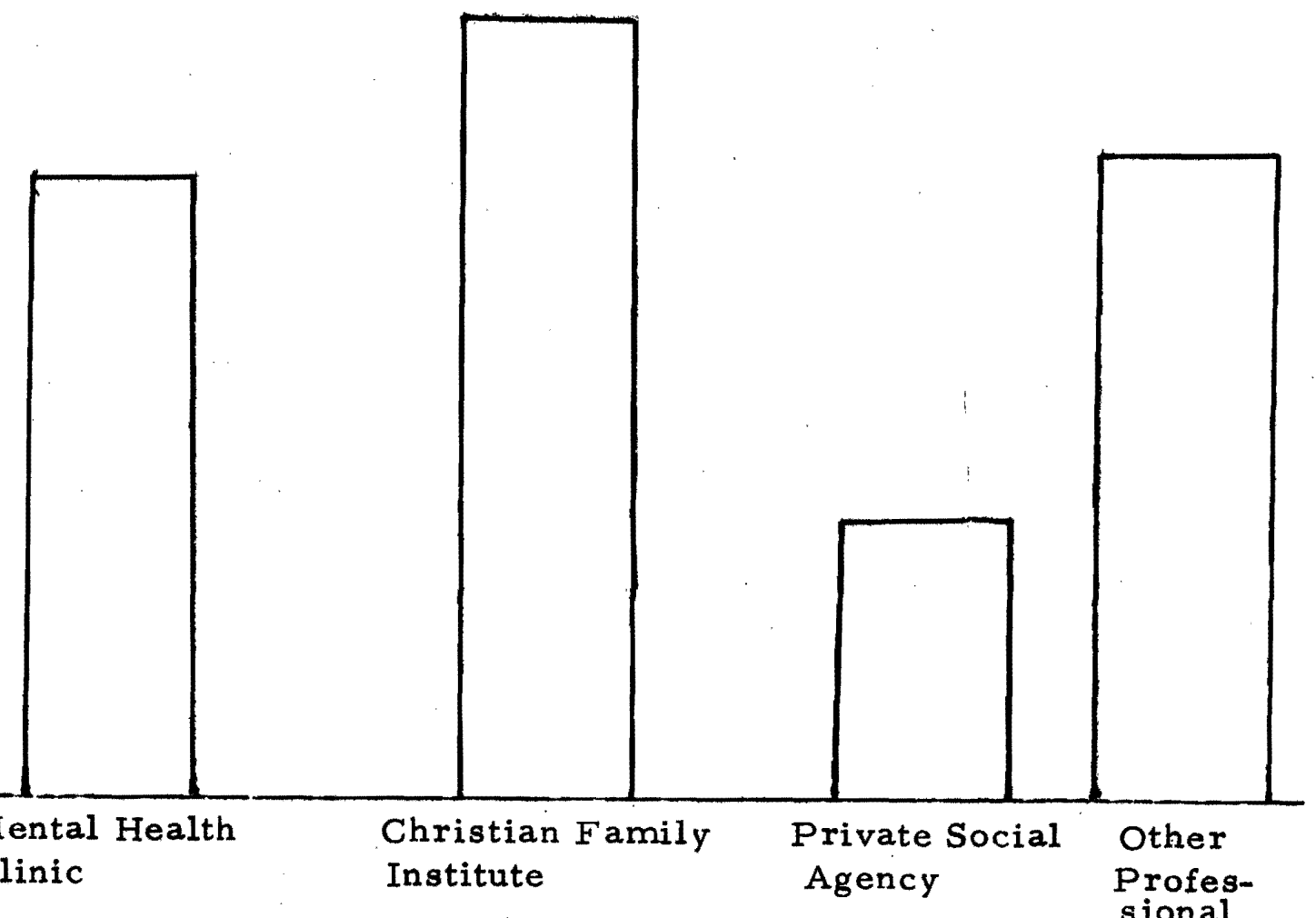
Mental Health Clinic

Because of the large number of mental health clinics within Oregon, most ministers should have had access to local clinics. Only 8 percent referred there often though, and 18 percent never utilized the resource. Over a third of the ministers did occasionally refer people there, which made it much more popular than a private agency. There was no correlation between having attended a mental health clinic Seminar and using it as a referral source.

\section{Christian Family Institute (CFI)}

As stated earlier, this is a specialized resource center, located in Eugene, and aimed primarily at Christians who need professional counseling. Because it is the only one of its kind within the Christian Church in Oregon, it was expected that ministers would use it extensively. Even though the results showed it to be more popular than any of the other suggested resources, only 18 percent of the ministers used it often, and 13 percent never referred people there. It is not knowr why more of the ministers did not utilize the service more. The ques tion of how often they refer people to the various services, may have been interpreted to mean from among all "clients", rather than fror: those clients who were referred. Also, the distance of some ministers from Eugene, may have made referral prohibiting. The minister who used Prayer in his counseling session was much more likely to refer. people to this Christian resource. About 23 percent of those who often 
utilized the service, also often used Prayer in their counseling sessions. No relationship was found between church size, or the year graduated, and the use of CFI as a referral source.

\section{Private Social Agency}

This resource was utilized least of the four suggested, with over a third of the ministers never referring people to a private Social Agency. Only 16 percent used it occasionally. It was not indicated whether the lack of referrals was because these agencies were not available, or because the ministers were distrustful and hesitant about transferring people to a private, secular agency for counseling. The question remains to be answered by further research.

\section{Other Professional}

Although the "other professional" was not identified, 44 percent of the ministers said that they occasionally referred people to another professional person for counseling. The factors which were involved in this one-to-one referral were not determined. 
TABLE XVI

FREQUENCY AND PERCENTAGE DISTRIBUTION OF HOW OFTEN PEOPLE ARE REFERRED

BY THE MINISTER TO SPECIFIED

RESOURCES

\begin{tabular}{lcc} 
Person Referred To & $\begin{array}{c}\text { Occa- } \\
\text { Never Seldom sionally Often Always }\end{array}$ Ans. \\
\hline
\end{tabular}

1. Mental Health Clinic
a. No. of Responses
$11 \quad 20$
23
b. Percentage of Total
$18 \% \quad 32 \%$
$37 \%$
5

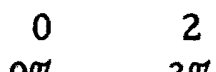

2. Christian Family Institute
a. No. of Responses
$8 \quad 12$
24
11
b. Percentage of Total
$13 \%$
$19 \%$
$39 \%$
$18 \%$

0

3. Private Social Agency
a. No. of Responses
b. Pexcentage of Total

$22 \quad 21$
$36 \% \quad 34 \%$
0
1.
$\begin{array}{rr}0 & 7 \\ 0 \% & 11 \%\end{array}$

4. Another Professional
a. No. of Responses
b. Percentage of Total
$\begin{array}{cl}5 & 14 \\ 8 \% & 22 \%\end{array}$
27
3
0
12
$8 \% \quad 22 \% \quad 44 \% \quad 4 \% \quad 0 \% \quad 19 \%$ 


\section{CHAPTER V}

\section{CONCLUSIONS}

\section{RESULTS}

This study has been concerned with establishing descriptive information regarding the Counseling of a specific population of ministers, and to indicate how those ministers evaluated the training that they received in counseling. Data was obtained through questionnaires, which were sent to all of the senior, full-time Christian Church ministers in Oregon who had graduated from Northwest Christian College: From a total population of 80,61 usable questionnaires were returned.

Five basic questions were established for consideration at the outset of the research project. Those questions, given in the introduction, are listed below with the findings from the survey.

1. How Important is Counseling in the Priorities of the Minister, and How Much Time is utilized each Week for Counseling?

A. Priorities - out of six possible pastoral duties listed, the average minister felt that Counseling was fourth in importance, ahead of planning and administration.

B. Time Spent in Counseling - The ministers ranged from no time to over 15 hours per week spent in Counseling. The average amount of time used for Counseling was 5-1/2 hours per week. 
C. Sessions - The average minister had 3-1/2 sessions

with each individual or family that he counseled.

2. What Kinds of Problems are Dealt with in the Minister's

Counseling Sessions?

A. Spiritual - This was the most prevalent problem dealt

with. Eighty-one percent said it was often or almost always the reason counseling was sought.

B. Family - Seen only slightly less often than Spiritual Problems.

c. Marital - Seen third in frequency, just behind family problems.

D. Death and Sickness - Seen almost as often as marital problems.

E. Interpersonal - Seen fifth in frequency, with 68 percert stating that was dealt with interpersonal problems often or almost always.

F. Pre-Marital - Just over half of the ministers saw Promarital problems often or almost always.

G. Alcohol and Drugs - Seen much less often than the above. Only 21 percent dealt with these problems often.

H. Sexual - Rarely dealt with as a problem.

I. Vocational - This problem area was dealt with very seldom by the ministers. 
3. What are the Procedures, Techniques, or Resources that the Minister Utilizes within the Counseling Process?

A. Listening - All of the ministers listened often or almost always in their counseling sessions.

B. Clarification - This was the second most utilized proce.dure.

$$
\text { C. Giving Information - } 71 \% \text { gave out information often or }
$$
almost always.

D. Prayer - $61 \%$ utilized prayer often or almost always ir. the counseling session.

E. Scripture Reading - $52 \%$ read from the Bible often or almost alviays in the counseling session.

F. Giving Advice - $41 \%$ gave advice often or almost always.

G. Meditation - $15 \%$ practiced meditation often or almost always in the counseling session.

4. How are People Referred to the Minister for Counseling, and How ofter, and Where does he refer them Elsewhere?

A. How are People referred to the Minister?

1) Person Seeking help - The vast majority of the rninister's clients were self-referrals.

2) Family - 36\% of the ministers received referral:3 from the family often or almost always. 
3) The Minister - $26 \%$ of the ministers often initiated the counseling contact themselves.

4) Friend - $24 \%$ often received referrals from the clients' friends.

5) Other Professionals - Only 6\% often received referrals from other professionals.

B. How Often Does the Minister make Referrals? $32 \%$ of the ministers indicated that they often referred individuals elsewhere as part of their counseling process. $42 \%$ selfom did.

C. Where does the Minister Make Referrals?

1) Christian Family Institute - This resource was the most frequently used of the four suggested. $56 \%$ used it occasionally or often.

2) Other Professional - Referrals were made to other professional people only slightly less often than to Christian Family Institute.

3) Mental Health Clinic - $45 \%$ of the ministers occas onally or often referred people to a mental health clinic.

4) Private Social Agency - Used only rarely by ministers. 5. How do the ministers evaluate the training that they have received in counseling, and what suggestions, if any, do they have regarding the counseling program at NCC? 
A. Evaluation of Training

1) NCC - The majority felt that it had not been helpful or only fairly helpful to them in being a Counselor. One-third thought that it had been very helpful.

2) Seminary - $61 \%$ indicated that they had attended seminary, and the majority of them believed that it had been very or extremely helpful to them in being a counselor.

3) Institutes and Seminars - $64 \%$ had attended one $0:$ more Institute or Seminar. Almost all of which were found to be ver, or extremely helpful.

\section{Suggestions regarding the NCC Counseling Program}

1) Have Supervised Counseling Experience - $75 \%$ of the ministers agreed with this suggestion. Only one minister dis agreed, and the rest did not state their opinion.

2) Add more Clinical Counseling Courses - $55 \%$

agreed, $12 \%$ did not.

3) Make more Counseling Courses Mandatory for Graduaticn $-41 \%$ agreed $-14 \%$ did not.

4) Add more Psychology Courses - 35\% agreed, 12\% did not, while the majority made no comment about this suggestion.

5) No Change Necessary - $14 \%$ were satisfied with the program the way it was, $43 \%$ were dissatisfied. 
6) Have fewer Counseling Courses - No one agreed with this suggestion, 64 percent disagreed. The remaining ministers made no comment.

\section{Impact for Northwest Christian College}

With respect to the above cited results, numerous implications $c$ an be made regarding the Counseling program at NCC. These results appear to have supported the informal hypothesis that was made at the beginning of the study--that these ministers are doing extensive counseling for which they have not been sufficiently trained or prepared. Although an average of 5 or 6 hours per week spent in counseling may not be seeri as extensive, it does represent a comparatively large investment cif time for the minister. Their evaluation of the Counseling training that they had received, indicated that it had generally not bes:n as adequate as it could have been, or as complete as the ministers wanted.

It wiss shown that perhaps as many as one-third of the graduates from NCC, who are now in the ministry, received their only formal education at NCC. It was also shown that ministers who go on to Serninary do not always receive adequate and helpful training in counseling. These facts place increased responsibility on NCC to prepare minis in becoming knowledgeable and effective counselors. The evaluation of the NCC Counseling program revealed that, on the average, the mirister was only slightly helped in becoming a Counselor. Most agreed 
that the program should be expanded and emphasized more than it is presently.

It is recognized that NCC cannot be all things to all people, and that expansion is one area usually leade to limitation in another. This study has not presumed to place the importance of counseling above all other subjects taught at NCC, but it has clearly shown that Counseling is an important and necessary part of the ministry, and an area in whi ih the ministers desire more training.

In cooperating with this study, Dr. Bixler has shown his openmindedness and interest in making the Counseling program more effective and sensitive to the needs of ministers.

The following recommendations are, therefore, made in light of this study:

1. Make the "Introduction to Counseling" Course Mandatory for all Ministerial Students.

2. Create field work or practicuum experiences in which students can do actual counseling in a controlled, Supervised environment. This Program would be similar in purpose to the Christian Education Practicuum alxeady used at NCC, and would place students in Christian Counseling settings throughout the area. The key to such a program is the Supervision, and it is believed that increased Chaplains, the staff at Christian Family Institute, or other Christian Professional Counselors could be utilized for this purpose. Senior students should be encouraged, 
if not required, to be involved in this program, and it should be mandatory for all Ministerial students who do not plan to go directly into Seminary.

3. Create more Counseling Seminars dealing with specific arei.s, such as:
a. Family Counseling
b. Marital Counseling
c. Counseling the Sick and Dying
d. Interviewing Techniques
e. Utilizing Community Resources
1'. Applying Biblical Concepts to Counseling

4. Sponsor Various Counseling Seminars and Institutes which would be directed to students, ministers and inte rested Christians. Because Seminars and Institutes were found to be so helpful, it is recommended that NCC sponsor various Training sessions, utilizing special sfeakers, and make them available, perhaps for credit, to students and graduates alike.

It is believed that if these recommendations were to be implemented by NCC, the Counseling program would be a more effective and viable influence in preparing ministers as Pastoral Counselors.

\section{Implication for Further Research}

As this was a Pilot Study, it builds the foundation for further and more exhaustive research. In order to obtain a more extensive 
evaluation oi the Counseling program at NCC, personal interviews should be obtained from those graduates who participated fully in the Couns eling program. That would allow for more open ended questions and more expression of feelings.

This study did not attempt to evaluate how effective the minister was in his counseling, and the goal of further research might be to determine what factors are involved in making a pastor successful or not. successful in his counseling. It would be difficult to operationally define terms, but the results would be invaluable to educators and ministers alike. All of the helping professions are now involved in evaluative research to determine their effectiveness, and ministers should also be concerned about that question.

To quote Clinebell $(1966)^{31}$ again:

"The pastor, regardless of his training, does not enjoy the privilege of electing whether or not he will counsel with his people. . His choice is not between counseling and not courseling, but between counseling in a disciplined and skilled way, and counseling in an undisciplined and unskilled way." 


\section{FOOTNOTES}

1. J. W. Feld and Sheila Feld, Americans View Their Mental Health (New York: Basic Books, 1960), p. 307.

2. Peter Davies, ed., The American Heritage Dictionary, (New York: Dell Publishing Co., Inc., 1969), p. 164.

3. Edwin Lewis, The Psychology of Counseling (New York: Holt, Reinhart and Winston, Inc., 1970), p. 4.

4. Seward Hiltner and Lowell Colston, The Context of Pastoral Counseling, (New York: Abingdon Press, 1961;, p. 7.

5. Donald F. Tweedie, Jr., The Christian and the Couch, (Grand Rapids: Baker Book House, 1963), p. 184 .

6. Howard Clinebell, Jr., B asic Types of Pastoral Counseling, (New York: Abingdon Press, 1966), p. 48.

7. Samuel Laycock, Pastoral Counseling for Mental Health, (New York: Abingdon Press, 1961), p. 11.

8. Tweedie, Gouch, p. 187.

9. Wayne Oates, An Introduction to Pastoral Counseling, (Nashville: Broadman Press, 1959), p. 4 .

10. Bible, The, I. Cor. 7

11. Oates, Introduction, p. 5.

12. Ibid., p. 8 .

13. Ibid., p. 12 .

14. Dugald, Arbuckle, Counseling: Philosophy, Theory and Practice, (Boston: Allyn and Bacon, Inc., 1969), p. 12.

15. Oates, Introduction, p. 15.

16. Hiltner, Context, p. 24. 
17. Ibid., p. 27.

18. Thomas C. Oden, Kerygma and Counseling, (Philadelphia: Westminster Press, 1966), p. 23.

19. Heije Faber and Ebel Van der Schoot, The Art of Fastoral Conversation, (New York: Abingdon Press, 1962), p. 41.

20. Clinebell, Basic, p. 51 .

21. Seward Hiltner, Pastoral Counseling, (New York: Abingdon Press, 1964), p. 121.

22. Clinebell, Basic, p. 51.

23. Hiltner, Context, p. 29.

24. Leslie Mosberg, Counseling - A Modern Emphasis in Religion, (New Jersey: Prentice Hall, Inc., 1962), p. 9.

25. Clinebell, Basic, p. 51.

26. Carroll Wise, Pastoral Counseling - its Theory and Practice, (New York: Harper and Brothers, 1951), p. 144.

27. Northwest.Christian College, NCC Bulletin and Catalogue, (Eugene, Oregon, 1972), p. 12.

28. Clinebell, Basic, p. 42.

29. Tweedie, Couch, p. 180.

30. Hiltner, Context, pp. 1-30.

31. Joseph W. Eaton., et a1, "Pastoral Counseling in a Metropolitan Suburb", Journal of Pastoral Care, (Summer, 1963), pp. 93 105.

32. Arbuckle, Philosophy, p. 12.

33. Tweedie, Gouch, p. 177.

34. Hiltner, Context, p. 164.

35. Wise, Theory, p. 164.

36. Tweedie, Couch, p. 176.

37. Clinebell, Basic, p. 1960. 


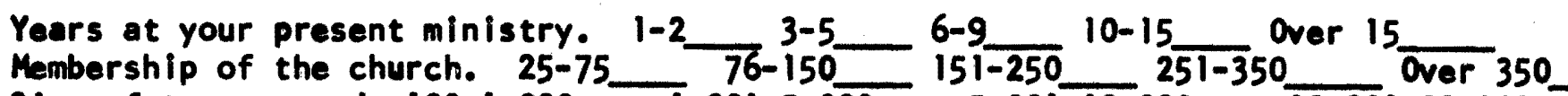

Size of town served. $100-1,000-1,001-5,000 \_5,001-10,000 \quad \overline{10,001-20,000}$

Over 20,000

How do you differentlate pastoral counseling from other kinds of counseling? List the ways it is unique.

In your estimation, rank the following pastoral dutles in order of their importance to yourself, your board, and your congregation. (Rank highest priority \#I)

- Adninistration

$$
\text { Duties Self }
$$

Board

Congreantion

b. Counselina

c. Evangellism

d. Plennina

e. Preaching

f. Teaching

g. Other (Specify)

On the average, how many hours do you spend in counseling others per week?

Rate how often the following problems are the primary reason that counseling is sciught. (circle your answer)
a. Interpersonal
Problem Areas
b. Family
c. Marital
d. Pre-marital
-. Sexual
f. Death and sickness
g. Spiritual
h. Vocational
I. Alcohol or drugs
j. Other (specify)

\begin{tabular}{cc} 
Mever & Seldom \\
\cline { 2 - 2 } 1 & 2 \\
1 & 2 \\
1 & 2 \\
1 & 2 \\
1 & 2 \\
1 & 2 \\
1 & 2 \\
1 & 2 \\
1 & 2
\end{tabular}

\begin{tabular}{c} 
Ho opinion \\
\hline 3 \\
3 \\
3 \\
3 \\
3 \\
3 \\
3 \\
3 \\
3 \\
3
\end{tabular}

\begin{tabular}{c} 
Often \\
\hline 4 \\
4 \\
4 \\
4 \\
4 \\
4 \\
4 \\
4 \\
4 \\
4
\end{tabular}

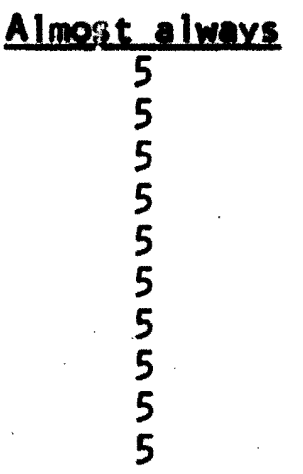

What do you do during an average counseling session? Rate how often the followirig are utllized.

\begin{tabular}{lccc}
\multicolumn{1}{c}{ Procedures } & Never & Seldom & No doinion \\
a. Prayer & 1 & 2 & 3 \\
b. Scripture reading & 1 & 2 & 3 \\
c. Meditation & 1 & 2 & 3 \\
d. Clarification & 1 & 2 & 3 \\
e. Giving advice & 1 & 2 & 3 \\
f. Listening & 1 & 2 & 3 \\
g. Giving information & 1 & 2 & 3 \\
h. Referring person somewhere else 1 & 2 & 3 \\
i. Other (specify) & 1 & 2 & 3
\end{tabular}

Rate how helpful the following have been in preparing you for the role of pastoral counselor.

Ireining received at: NCC

Hot

helpful helpful

Year graduated

Seminary

Name

Years attended

Institutes or Seminars

Identify 
Rate your agreement to the following suggestions regarding the NCC counseling program.

\section{Sugaestions}

a. No change necessary

b. Add more clinical counseling courses

c. Add more psychology courses

d. Have supervised counseling experience

e. Have fewer counseling courses

f. Make more counseling courses mandatory for graduation

g. Other (specify)
Strongly disagree
No $\frac{\text { Disagree }}{2}$ $\frac{\text { opinion }}{3}$

$\frac{\text { Aaree }}{4}$

Strongly

agree

5

$\begin{array}{lllll}1 & 2 & 3 & 4 & 5 \\ 1 & 2 & 3 & 4 & 5 \\ 1 & 2 & 3 & 4 & 5 \\ 1 & 2 & 3 & 4 & 5 \\ 1 & 2 & 3 & 4 & 5 \\ 1 & 2 & 3 & 4 & 5\end{array}$

Who initiates the counseling process in your present ministry?

\section{Source}

a. Person seeking help

b. Family

c. Friend

d. You

e. Other professional

f. Other (specify)

\begin{tabular}{cc} 
Occasionally & Often \\
\cline { 1 - 2 } 3 & 4 \\
3 & 4 \\
3 & 4 \\
3 & 4 \\
3 & 4 \\
3 & 4
\end{tabular}

Almost always

What is the average number of counseling sessions that you have with any one individual or family? 2-3 4-6 7-10 Over 10

How often do you refor people to the following services?
Person referred to:
a. Mental health clinic
Never
$\frac{\text { Seldom }}{2}$
$\frac{\text { Ocansionally }}{3}$
$\frac{\text { Often }}{4}$
Almost al vays

b. Christian Family Institute

c. Private social agency

d. Other professional

e. Other (specify)

1

2
2
2

3
3
3

4

4

4

5
5
5

1

2

3

4

5

Comments : 
Dear Sir:

I am writing to you to ask for your help in a Thesis Project I am doing for the Graduate School of Social Work at Portland State University. My toplc of study is Pastoral Counseling and $I$ am focusing on two primary areas:

1. The nature and extent of Pastoral Counseling that you do, and

2. How you evaluate the training in Pastoral Counselling that you have received, especially from Northwest Christian College.

A copy of the enclosed questlonalre has been sent to all of the Christian Church - Church of Christ ministers in Oregon who have graduated from NCC and are currently serving as senior pastor in a church. If the results are to be valid, it is necessary that you fill out the enclosed questionaire (both sides) and return it to me as soon as possible with the envelope provided.

Although this study is in no way sponsored by NCC, it is done with their knowledge and cyoperation, and the results may be used by them in evaluating their counseling curriculum.

Your individual responses will, of course, be kept confidentlal but the final results will be made available to you if you so desire.

Your efforts in making thisetudy meaningful are greatly appreciated.

Respectfully,

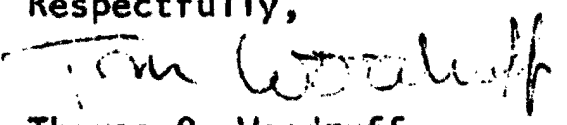

Thomas 0 . Woodruff

3132 S.H. Marigold Apt. 8

Portland, Oregon 97219 


\section{APPENDIX C}

\section{FREQUENCY AND PERCENTAGE DISTRIBUTION}

OF THE IMPORTANCE OF PASTORAL

DUTIES TO THE MINISTER, HIS

$$
\text { BOARD, AND THE }
$$

CONGREGATION

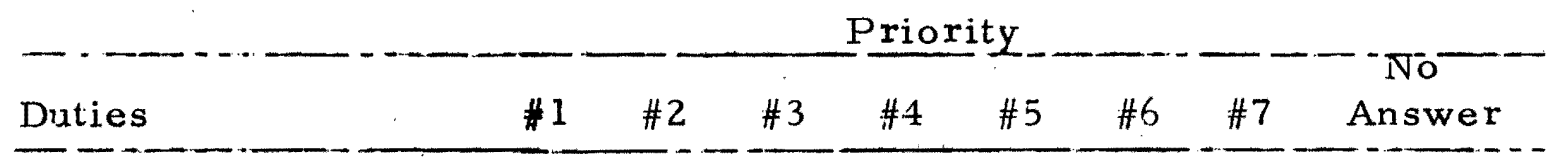

1. Administration

a. Self
1) Nc. of $\mathrm{Re}$ - sponses
2) Percent of Total

$\begin{array}{lllllll}1 & 4 & 7 & 6 & 16 & 15 & 1 \\ 1 \% & 6 \% & 11 \% & 9 \% & 26 \% & 24 \% & 1 \%\end{array}$

b. Board
1) No, ố $\mathrm{Re}$ - sponses
Percent of $\begin{array}{lllllll}4 & 7^{\circ} & 8 & 13 & 10 & 6 & 2\end{array}$
2) Percent of Total

c. Congregation

1) No. of $\mathrm{Re}$ sponses

2) Percent of Total

$\begin{array}{lllllll}0 & 3 & 9 & 11 & 14 & 10 & 1\end{array}$

12 $0 \% \quad 4 \% \quad 14 \% \quad 18 \% \quad 22 \% \quad 16 \% \quad 1 \%$ $19 \%$

2. Evangelism

a. Self

1) Nio. of $\mathrm{Re}-$ sponses

2) Fercent of Total

$\begin{array}{lllllll}14 & 8 & 10 & 7 & 8 & 2 & 1\end{array}$

11

$22 \% \quad 13 \% \quad 16 \% \quad 11 \% \quad 13 \% \quad 3 \% \quad 1 \% \quad 18 \%$

b. Board
1) iNo, of Re- sponses
9
$13 \quad 12 \quad 6$
$7 \quad 2$
0
12
2) Percent of Total


Priority

Duties

c. Congregation

1) No. of $\mathrm{Re}$ sponses

2) Percent of Total

$\begin{array}{lllllll}11 & 14 & 12 & 8 & 6 & 1 & 0\end{array}$

9 $18 \% \quad 22 \% \quad 19 \% \quad 13 \% \quad 9 \% \quad 1 \% \quad 0 \% \quad 1.4 \%$

3. Planning

a. Self

1) No. of. $\mathrm{Re}-$ sponses

2) Percent of Iotal

$\begin{array}{llllllll}5 & 2 & 5 & 11 & 14 & 14 & 0 & 10\end{array}$

$8 \% \quad 3 \% \quad 8 \% \quad 18 \% \quad 22 \% \quad 22 \% \quad 0 \% \quad 16 \%$

b. Board

1) No. of Responses

2) Percent of Total

$\begin{array}{llllllll}3 & 5 & 9 & 6 & 7 & 17 & 1 & 13\end{array}$

$4 \% \quad 8 \% \quad 14 \% \quad 9 \% \quad 11 \% \quad 27 \% \quad 1 \% \quad 21 \%$

c. Congregation

1) No. of Responses

2) Percent of Total

$\begin{array}{llllllll}1 & 1 & 6 & 6 & 11 & 23 & 2\end{array}$

11

$1 \% \quad 1 \% \quad 9 \% \quad 9 \% \quad 18 \% \quad 37 \% \quad 3 \%$

$18 \%$

4. Preaching

a. Self

1) No. of $\mathrm{Re}-$ sponses

2) Percent of Total

$\begin{array}{llllllll}18 & 15 & 7 & 5 & 1 & 2 & 0 & 13\end{array}$

$29 \% \quad 24 \% \quad 11 \% \quad 8 \% \quad 1 \% \quad 3 \% \quad 0 \% \quad 21 \%$

b. Board

1) NJo, of $\mathrm{Re}-$ $\leq$ ponses

2) Percent of Total

$\begin{array}{llllllll}29 & 5 & 7 & 2 & 0 & 2 & 0 & 15\end{array}$

$47 \% \quad 9 \% \quad 11 \% \quad 3 \% \quad 0 \% \quad 3 \% \quad 0 \% \quad 24 \%$

c. Congregation

1) No. of $\mathrm{Re}$ sponses

2) Percent of Total 


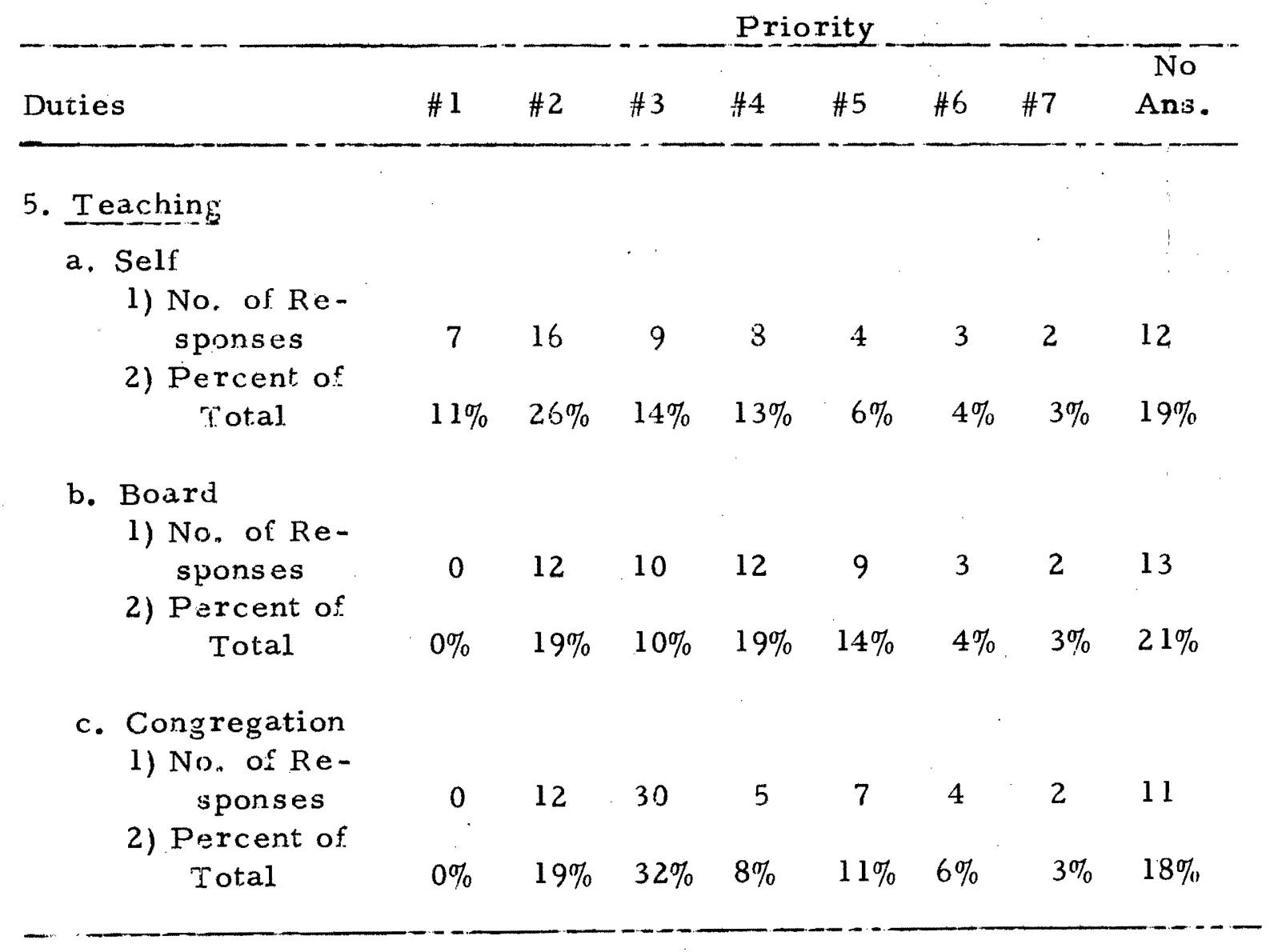




\section{BIBLIOGRAPHY}

Arbuckle, Dugald S., Counseling: Philosophy, Theory and Practice, Boston: Allyn and Bacon, Inc., 1969.

Bentz, W. K., "The Relationship between Educational Background and the Referral Role of Ministers", Sociology and Social Research, 51, (July, 1962), 199-208.

Bible, I. Cor. 7.

Clinebell, Howard J., Jr., Basic Types of Pastoral Counseling, New York: Abingdon Press, $19 \overline{66 .}$

Davies, Peter, ed., The American Heritage Dictionary, New York: Dell Publishing Co., Inc., 1969 .

Eaton, Joseph W., et al, "Pastoral Counseling in a Metropolitan Suburb", Journal of Pastoral Care, (Summer, 1963), 93.. 105.

Faber, Heije and Van der Schoot, Ebel. The Art of Pastoral Conversation, New York: Abingdon Press, 1962.

Farnsworth, Donna L. and Bracelord, Francis J., Psychiatry, The Clergy and Pastoral Counseling, Collegeville, Minnesota: St. Johns University Press, 1969.

Gurin, J. W. and Feld, Sheila, Americans View Their Mental Healtr, New York: Basic Books, 1960.

Hiltner, Seward, Pastoral Couns elíng, New York: Abingdon Press, 1964. , and Colston, Lowell. The Context of Pastoral Coix:1seling., New York: Abingdon Press, 1961 .

Kemp, Charles F., A Pastoral Counseling Guidebook, New York: Abingdon Press, $\overline{1} \overline{7}$.

Lewis, Edwin C., The Psychology of Counseling, New York: Holt, Rinehart and Winston, Inc., 1970.

Laycock, Samuel," Pastoral Couns eling for Mental Health, New York: Abingdon Press, 1961 . 
Mendenhall, William, Introduction to Probability and Statistics, Belmont, Calif. : Wadsworth Publishing Co., Inc., 1967.

Mikesell, William H., Counseling for Ministers, Boston: The Christopher Publishing House, $196 \mathrm{~L}$.

Mosberg, Leslie E., Counseling - A Modern Emphasis in Religion, New Jersey: Prentice Hall, Inc., 1962.

Northwest Christian College, 1972-73 Bulletin and Catalogue, Eugene, Oregon, 1972.

Oates, Wayne E., An Introduction to Pastoral Counseling, Nashville, Tenn.: Broadman Press, 1959.

Oden, Thomas C., Kerygma and Counseling, Philadelphia: Westminster Press, 1966.

Oglesby, William B., Jr., Referral in Pastoral Counseling, New Jersey: Prentice Hall, Inc., 1968.

Pacella, 3. L., "A Critical Appraisal of Pastoral Couns eling", American Journal of Psychiatry, 123 (Oct., 1966), 646-651.

Phillips University. 1971-73 Seminary Catalogue, Enid, Oklahoma, 1971.

Claire Selltiz, et al, Research Methods in Social Relations, New Ycrk: Holt, Rinehart and Winston, 1951 .

Tweedie, Donald F., Jr., The Christian and The Couch, Grand Rafids: Baker Book House, 1963.

Wise, Carroll A., Pastoral Couns eling - Its Theory and Practice, New York: Harper and Brothers, 1951 . 